\title{
Revision of the tsunami catalogue affecting Turkish coasts and surrounding regions
}

\author{
Y. Altinok ${ }^{1}$, B. Alpar ${ }^{2}$, N. Özer ${ }^{1}$, and H. Aykurt ${ }^{1}$ \\ ${ }^{1}$ Istanbul University, Engineering Faculty, Geophysical Engineering Department, 34320, Avc1lar, Istanbul, Turkey \\ ${ }^{2}$ Istanbul University, Institute of Marine Sciences and Management, 34116, Vefa, Istanbul, Turkey
}

Received: 3 May 2010 - Revised: 9 December 2010 - Accepted: 10 December 2010 - Published: 2 February 2011

\begin{abstract}
The coasts of Turkey have been hit by tsunamis in the past. The first national earthquake-tsunami catalogues were compiled in the early 1980s while the most up-to-date tsunami catalogues are mainly the products of recent European projects. The EU projects GITEC and GITEC-TWO (Genesis and Impact of Tsunamis on the European Coasts) and TRANSFER (Tsunami Risk ANd Strategies For the European Region) have added important contributions in establishing and developing unified criteria for tsunami parameterisation, standards for the quality of the data, the data format and the database general architecture. On the basis of these new aspects and based on recent marine geophysical data, tsunamigenic earthquakes, tsunami intensities and their reliability have been revised. The current version of the database contains 134 events, most of which have affected the Turkish coasts seriously during the last 3500 years. The reliability index of 76 events was "probable" and "definite", so that they could be used for assessment of the risk along the Turkish coastal region and for implementation of prevention policies.
\end{abstract}

\section{Introduction}

Destructive tsunamis have impacted many coastal communities in all of the world's oceans and seas throughout human history. The Eastern Mediterranean, including the Aegean and Black Seas, is one of these regions where many ancient descriptions of sudden and catastrophic waves have been recorded. The active tectonics of this region are the result of interactions between the northward moving African and Arabian plates and the relatively stable Eurasian Plate since the Early Pliocene (Bozkurt, 2001). The long history of devastating earthquakes is characterized by three main unique structural elements: the North Anatolian Fault Zone (NAFZ) in the North, the East Anatolian Fault Zone (EAFZ) in the East, and the Aegean-Cyprean Arc in the southern Aegean Sea (Fig. 1). The Dead Sea Fault Zone (DSFZ) interacts with the tectonics of the Cyprean Arc and has also produced big earthquakes.

Reliable tsunami databases are of great importance for a wide range of tsunami-related studies including risk evaluation, hazard assessment, wave numerical modeling and public awareness. Some of the events affecting the Turkish coasts have been mentioned previously in the tsunami catalogues and databases compiled by earlier researches: e.g. Galanopoulos (1960), Ambraseys (1962), Antonopoulos (1979), Papadopoulos and Chalkis (1984) and Papazachos et al. (1986). The first Turkish catalogue of tsunamis, on the other hand, was compiled by Soysal et al. (1981). The consequences of such events, in view of increasing coastal urbanization, can be extremely serious. The Turkish coasts are about $8300-\mathrm{km}$-long with many territorial divisions found along the low-lying coasts where about one third of the population lives (Alpar, 2009).

In the present study all available catalogues, source documents and quantitative data obtained from recent marine geophysical data have been re-examined based on the guidelines defined in GITEC (Genesis and Impact of Tsunamis on the European Coasts) and TRANSFER (Tsunami Risk ANd Strategies For the European Region) projects. The sedimentary, chemical and age data obtained from recent core samples, which may represent candidate tsunami deposits, also provided a confirmation for the catalogue data.



Correspondence to: Y. Altinok

(yaltinok@istanbul.edu.tr)

Published by Copernicus Publications on behalf of the European Geosciences Union. 




Fig. 1. The neotectonics of Turkey is characterized by three main strike-slip fault zone systems and a subduction zone along the Aegean and Cyprean arcs (Şaroğlu et al., 1992; Bozkurt, 2001). DSFZ - Dead Sea Fault Zone, EAFZ - East Anatolian Fault Zone, NAFZ - North Anatolian Fault Zone, NEAFZ - Northeast Anatolian Fault Zone. Stars indicate the source locations of the tsunamis defined in the present study.

\section{Data}

In the present study, not to mislead readers, the tsunami records are generally in the form of a collection from previous catalogues and literature papers. We have been selective, however, with the dates (in bold) and locations of the events and concerning their reliability. As for this reliability of the events, the GITEC Catalogue criteria (Tinti et al., 2001; UNESCO/IOC Global Tsunami Website) have been considered: i.e. 0: very improbable, 1: improbable, 2: questionable, 3: probable and 4: definite tsunami. Beyond building up a standardised catalogue of tsunamis, the most important contribution of the present study has been the search for the events of 407, 545, 549, 551, 557, 740, $989,1265,1481,1509,1598,1766,1856.10 .12,1867,1881$, 1893, 1894, 1901, 1912, 1935, 1939, 1944, 1949, 1956, 1961, 1963, 3 September 1968 and 1999. Most of the sources we searched were in the Ottoman and Turkish languages. We made efforts to reach the primary sources in order to avoid ambiguities and confusions. In this sense, the Ottoman Archives, manuscripts, old newspapers and magazines at various libraries have been searched. The number of scanned records throughout various catalogues between the years of 2005 and 2009 is more than 958 million. The most important records were "Bab-i Asafi Kalemi" (25 610), "Iradeler of 1255-1309" (150528), “Iradeler of 1310-1334" (142095), "Maliyeden Müdevver Defterler" (2 626910), "Dosya Usûlü Iradeler" (89 files), "Surayi Devlet" (<1260000), "Mühimme Defterleri" (29260), "Sicill-i Ahval Defterleri" (22 110), "Y1ldız Fonu Defterleri"
(2 248 303), "Maliye Nezareti Defterleri" (5 334 340), "Bâb1 Ali Evrak Odası (Ayniyat Defterleri Sadaret Defterleri, Amedi Kalemi Defterleri)" (4 146 627), "Bâb-1 Defteri Fonu Defterleri" (10 258344), "Dahiliye Nezareti Defterleri" (4 209 936), "Meclis-i Vükelâ Mazbata" (65 670), "Meclis-i Vâlâ Fonu Defterleri”" (425 845) and Naval Museum archives of Istanbul (Mektubi 1, Şura-i Bahri and Belge Katalogları). Meanwhile, many related documents were searched in the Turkish Republic Archives (Cumhuriyet Arşivi) and Turkish Parliament (TBMM) Library, other local libraries (Istanbul Atatürk, Istanbul Beyazıt, Süleymaniye, Istanbul Üniversitesi Merkez Kütüphanesi, Istanbul Kitaplığı, Koraes Library in Chios, Bozcaada Halk Kütüphanesi, Fethiye Halk Kütüphanesi, İzmir Milli Kütüphanesi, İzmir Şehir Kütüphanesi, Çeşme Kütüphanesi, ISAM Kütüphanesi) and archives (Gökçeada, Foça and Ayvalık municipalities). Besides the archives and libraries, we have also studied other sources of printed matter of documentary character such as novels and diaries. The Turkish catalogue of tsunamis was prepared using the international codes and reference numbers given below.

Regional codes: Black Sea (BS), Sea of Marmara (SM), North Aegean (NA), Central Aegean (CA), South Aegean (SA), East Mediterranean (EM).

Cause codes: Volcanic associated (VA), Earthquake associated (EA), Earthquake landslide (EL), Submarine earthquake (ER), Submarine eruption (VO), Earthquake marine slide (ES).

Source codes: Source coordinates: Latitude (N), Longitude $(\mathrm{E})$; Earthquake epicentral intensity $\left(I_{0}\right)$, Earthquake Intensity (I), Earthquake maximum intensity $\left(I_{\max }\right)$, Earthquake magnitude: $\mathrm{M}$ (mostly $\mathrm{M}_{\mathrm{L}}, \mathrm{M}_{\mathrm{S}}$ and $\mathrm{M}_{\mathrm{W}}$ ), Earthquake depth in $\mathrm{km}(\mathrm{h})$, Affected Areas by earthquake (AA), Tsunami Intensities: TI1 (Sieberg-Ambraseys Scale; Ambraseys, 1962); TI2 (Papadopoulos-Imamura Scale; Papadopoulos and Imamura, 2001), Water level rise in metres (Wr), Run-up in metres (Rp), Reliability (Rel).

Reference numbers (in alphabetical order): (1) Alptekin et al. (1985); (2) Altinok and Ersoy (2000); (3) Altinok et al. (2001); (4) Altinok et al. (2003); (5) Altinok et al. (2005); (6) Altinok and Alpar (2006); (7) Altinok et al. (2007); (8) Altinok et al. (2009); (9) Altinok and Alpar (2010); (10) Ambraseys (1960); (11) Ambraseys (1962); (12) Ambraseys and Finkel (1987); (13) Ambraseys (1988); (14) Ambraseys and Finkel (1995); (15) Ambraseys (2002a); (16) Ambraseys (2002b); (17) Antonopoulos (1987); (18) Birand (1944); (19) BOA, YEE, 91/19; (20) Bryant (2001); (21) Calvi (1941); (22) Eginitis (1894); (23) Fokaefs and Papadopoulos (2007); (24) Guidoboni et al. (1994); (25) Guidoboni and Comastri (2005); (26) Heck (1947); (27) İkdam, 5 April 1901; (28) Karnik (1971); (29) Kuran and Yalçıner (1993); (30) Luttrell (1999); (31) Moreria (1971); (32) Murty (1977); (33) Nikonov (1997a); (34) Nikonov (1997b); (35) Ozansoy (1999); (36) Ozansoy (2001); (37) Özçiçek (1966-1967); (38) Öztin 
and Bayülke (1991); (39) Öztin (1994); (40) Papadimitriou and Karakostas (2006); (41) Papadopoulos and Chalkis (1984); (42) Papadopoulos (1993); (43) Papadopoulos et al. (2007); (44) Papazachos et al. (1986); (45) Papazachos and Papazachou (1997); (46) Parejas et al. (1942); (47) Poirier and Taher (1980); (48) Ranguelov (1996a); (49) Reinhardt et al. (2006); (50) Rothaus et al. (2004); (51) Sakin (2002); (52) Sbeinati et al. (2005); (53) Shebalin et al. (1974); (54) Soloviev et al. (2000); (55) Soysal et al. (1981); (56) Soysal (1985); (57) Stiros (2010); (58) Tinti et al. (2006); (59) Ulus, 24 May 1961; (60) Vatin (1999); (61) Vogt (1999); (62) Wedding (1968); (63) Yalçıner et al. (1999); (64) Yalçıner et al. (2000); (65) Yalçıner et al. (2004); (66) Yeni Sabah, 10 July 1956; (67) Yolsal et al. (2007); EMSC (European Mediterranean Seismological Centre); GITEC Catalogue (Genesis and Impact Tsunami on European Coast); KOERI (Kandilli Observatory).

\section{List of tsunamis}

The current version of the database contains the data on 134 tsunamigenic events that have occurred on and near the Turkish coasts from 17th century BC to the recent 1999 event in the Sea of Marmara.

1. 1410 \pm 100 BC: $1700-1380 \mathrm{BC}(54), 1600-1500 \mathrm{BC}$ (56); SA; VA; $36.5^{\circ} \mathrm{N}-25.5^{\circ} \mathrm{E}(55) ; I_{0}: \mathrm{X}-\mathrm{XII}$ (55); TI1: 6? (11), Rel: 3.

Earthquakes and a tsunami accompanied the eruption of the Santorini volcano. The Minoan Kingdom ceased to exist on the Aegean islands (2, 17, 41, 53, 54, 56).

2. $\mathbf{1 3 6 5} \pm 5$ BC: $\sim 1365 \mathrm{BC}(52), 1356 \mathrm{BC}$ (23); EM; ER; $35.68^{\circ} \mathrm{N}-35.8^{\circ} \mathrm{E}(23) ;$ : VIII-IX in Ugharit $(52,67)$; AA: half of the Ugharit burnt (52); Rel: 2.

Tsunami at Syrian coast (23).

3. 1300 BC: NA; ER; TI1: 6? (11, 41), 5 (54); Rel: 2.

Tsunami along the shore of the Ionian Sea and in Asia Minor, Dardanelles, Troy $(2,11,17,41,56)$.

4. 590 BC: EM; EA; I: Tyre VII? (52); $\mathrm{M}_{\mathrm{L}}$ : 6.8 (67); Rel: 2.

Tsunami at Tyre and on the Lebanese coast $(52,67)$.

5. 525 BC: EM; EA; I: Tyre VIII-IX (52); $\mathrm{M}_{\mathrm{L}}$ : 7.5 (67); Rel: 2.

Tsunami at Bisri and on the Lebanese coast $(52,67)$.

6. $330 \mathrm{BC}$ : NA; ER; $40.1^{\circ} \mathrm{N}-25.25^{\circ} \mathrm{E}(55) ; I_{0} \geq \mathrm{IX}$ (53); Rel: 3.

An underground shock near the western shore of Lemnos island generated a strong tsunami $(2,11,17,41,53$, $54,55)$.
7. 227 BC: 222 BC (2, 55), 220/222/227 BC (54); SA; ER; 36.6-28.25 (43); $I_{0}$ :(IX); M: (7.5) (45); AA: Rhodes, Cyprus, Corinth (2, 10, 11, 21, 41, 53); TI1: 3 (54); Rel: 3.

Tsunami associated with a large shock in Rhodes (43); originated on the northern shore of the islands of Rhodes and Tilos; many ships were destroyed (54).

8. 140 BC: $138 \mathrm{BC}(11,54)$; EM; ER; 33.0N-35.0E (55); $I_{0}$ : VIII (55); Rel: 2-3.

Silifke region in Turkey was affected by the tsunami (2, 55); tsunami between Akka and $\operatorname{Sur}(21,23,54)$.

9. 92 BC: EM; EA; I: Syria III-IV, Egypt III-IV (52); $\mathrm{M}_{\mathrm{L}}$ : 7.1 (67); Rel: 2.

Tsunami hit Levantine coastal cities, mostly SyrianLebanese coast $(52,67)$.

10. 26 BC: $23 \mathrm{BC}$ (23); EM; ER; 34.75N-32.4E (55); $I_{0}$ : VII (55); TI1:3 (11, 23), TI2:5 (23); Rel: 2.

Tsunami at Pelusium-Egypt (23); tsunami at PaphosCyprus $(2,11,17,55)$.

11. 20 \pm 20: 50 (55); BS; EA; $43.0^{\circ} \mathrm{N}-41.0^{\circ} \mathrm{E}(33) ; I_{0}$ : VIII (55); $M \geq 6.5$ (33); h: 20 (33); AA: Colchis Shore, Sukhumi Bay, the submersion of the ancient town of Dioscuria on the coast of the Sukhumi Bay, Colchis, can be inferred both from local legend and from the archeological remains at the sea bottom $(8,33,65)$; TI1: $4-5$ (33), TI2: 4-6 (65); Wr: $\geq 2.5$ (33); Rel: 3-4.

The waves were more than $2.5 \mathrm{~m}$ high in Sukhumi and were associated with an $\mathrm{M}=6.5$ earthquake (8).

12. 46: $\mathrm{SA} ; \mathrm{VA} ; 36.4^{\circ} \mathrm{N}-25.4^{\circ} \mathrm{E}$ (45); $I_{0}$ : VIII (55); M: (6.5) (45); AA: North east of Crete, Santorini Isl. (2, $11,17,41,53,55)$, south coast of Crete (11); eruption of Santorini Volcano (41); TI1: 3 (54); Rel: 3.

Tsunami observed in Crete (45).

13. 62: $66(41,53), 53 / 62 / 66(2,24), 46 / 62 / 66(54)$; at noon (55); SA; ER; $34.8^{\circ} \mathrm{N}-25.0^{\circ} \mathrm{E}(45) ; I_{0}$ : IX (55); M: (7.0) (45); AA: Southern coasts of Crete, Lebena (2, 11, $17,54)$ and northern coast of Crete $(55)$; TI1: $3(11,54)$; Rel: 4.

The sea receded about $1300 \mathrm{~m}$ (45); the sea in Lebena retreated about $100 \mathrm{~m}$ from the waterline (54).

14. 68: EM; ER; AA: Demre and Patara region of Lycia (2, 24); Rel: 2.

The sea retreated along the coast of Alexandria, Egypt and covered the coast of Lycia; the dark waters of the sea spread sand over Patara (24). 
15. 76: 77-78 (21), 76/77 (54); EM; ER; $I_{0}: X(55)$; AA: Larnaka, Paphos, Salamis-Cyprus (2, 10, 11, 17, 55, 56); TI1: 4 (54); Rel: 2.

The earthquake was accompanied by tsunami waves seen mostly in Kition, Paphos, Salamis (54).

16. 13 December 115: at night (23); EM; ER/EL; $36.25^{\circ} \mathrm{N}-36.10^{\circ} \mathrm{E}(55) ; I_{0}$ : (IX) (55); $\mathrm{M}_{\mathrm{L}}: 7.4$ (67); AA: Antioch region, Mt. Casius $(24,55)$; probably triggered by an earthquake generated on the Cyprian Arc fault system (49); Rel: 3.

Possible landslide (24); tsunami waves hit Caesaria, the Lebanese coast and Yavne $(52,67)$.

17. 10 October 123: $120(54,55), 10$ October 120 (45), 120/128 (24); SM; EA; $40.7^{\circ} \mathrm{N}-29.1^{\circ} \mathrm{E}(45,54)$; I: IXXI (24); M: (7.2) (45); AA: Kapidağ Peninsula (Cyzicus), Iznik and Izmit (24, 55); TI1: 2 (54); Rel: 3.

The sea flooded into the Orhaneli (Rhyndacus) River (6, 24).Tsunami in Izmit (54).

18. 142: 144 (55); 148 (41, 43, 44), 142/144 (24); SA; ER; $36.3^{\circ} \mathrm{N}-28.6^{\circ} \mathrm{E}(45)$; I: Rhodes IX (45); M: 7.6 (45); TI1: 3 (11, 41, 44), $3(43,54)$, TI2: 6 (43); Rel: 3-4.

A destructive shock caused a strong tsunami in Rhodes, Fethiye Gulf, Kos, Seriphos, Syme, Caria, Lycia (2, 11, 17, 24, 41, 44, 56); destructive sea inundation (43); the sea water penetrated deep into dry land for several miles (54).

19. 262: $261-262(2,56) ; \mathrm{SA} ; \mathrm{ER} ; 36.5^{\circ} \mathrm{N}-27.8^{\circ} \mathrm{E}(43)$; $I_{0}$ : IX (55); AA: South coast of Anatolia (2, 11, 17, 24), west Anatolia (54); TI1: 4? (11), 4 (54); 4 (54); Rel: 2.

Sea inundation (43); many cities were flooded by the sea, possibly tsunami (54).

20. 300: $293-306$ (2, 24); EM; ER; $35.2^{\circ} \mathrm{N}-33.9^{\circ} \mathrm{E}(23)$; I: IX-XI (24); Rel: 1.

Great part of Salamis-Cyprus was plunged into the sea by the earthquake $(23,24)$.

21. 2 April 303: 303/304 (24), 303-304 (52, 67), 306 (55); EM; ER; $33.8^{\circ} \mathrm{N}-34.3^{\circ} \mathrm{E}(52) ; I_{0}$ : VIII-IX (52); $\mathrm{M}_{\mathrm{L}}$ : 7.1 (67), $\mathrm{M}_{\mathrm{S}}$ : 7.1 (52); h: 20 (52); AA: Sidon, TyreSyrian (24, 55); Rel: 2.

Tsunami in Caesaria in Palestine $(52,67)$.

22. 342: EM; ER; $\left(34.75^{\circ} \mathrm{N}-32.4^{\circ} \mathrm{E}\right)$ (55); I: IX-XI (24); AA: Paphos, Famagusta, Salamis, Larnaka-Cyprus (2, 11, 17, 24, 54, 55, 56); TI1: 3 (54); Rel: 4.

The harbour of Paphos slid down into sea (54); the tsunami waves were observed on the SW, S and SE shores of Cyprus and in the Bay of Famagusta (54).
23. 344: NA; EA; $40.3^{\circ} \mathrm{N}-26.5^{\circ} \mathrm{E}$ (GITEC); AA: Çanakkale region, Thracian coasts $(2,11,17,56)$; TI1: Dardanelles 3, Thrace coasts 4 (11); Rel: 1.

24. 348: 348/349 (24), 348-349 (52, 67); 349 (55); EM; $\mathrm{EA} / \mathrm{ER} ; 33.8^{\circ} \mathrm{N}-33.5^{\circ} \mathrm{E}(55) ; I_{0}$ : (IX) (55); $\mathrm{M}_{\mathrm{L}}: 7.0$ (67); AA: Beirut-Leban $(24,55)$; Rel: 2.

Possible tsunami (52); a tsunami was observed on the Arwad island, the Syrian coast and in Beirut (54).

25. 24 August 358: SM; EL; $40.75^{\circ} \mathrm{N}-29.96^{\circ} \mathrm{E}(55) ; I_{0}$ : (IX) (55); M: 7.4 (15); AA: Izmit Gulf, Iznik, Istanbul (2, 15, 18, 21, 55, 56); Rel: 4.

The damaging waves in Izmit could have been generated by coastal landslides (15).

26. 21 July 365: In the morning (24); SA; ER; $35.2^{\circ} \mathrm{N}-$ $23.4^{\circ} \mathrm{E}$ (45); I: X-XI (24); $\mathrm{M}_{\mathrm{w}}$ : 8.5+ (57); AA: East Mediterranean, Crete, Greece, Adriatic coasts, Alexandria, West Anatolia (2, 10, 11, 17, 24, 26, 41, 44, 53, 55); TI1: Methoni, Epidaurus, Crete 4, Adriatic coasts, Alexandria, Sicily 3+ (11), Epidaurus, Crete 4, Alexandria, Albania, Sicily 4 (41), Crete 6, Epidaurus 4+, Methoni 4, Alexandria 3+ (44); Rel: 4.

First the sea was driven back and then huge masses of water flowed back (45); shipwrecks were found $2 \mathrm{~km}$ off the coastal line on the southwestern shore of Peloponnessus near Methoni $(41,54)$; tsunami was observed in Asia Minor; the coast of Sicily was flooded (54).

27. 11 October 368: SM; EA; $\left(40.4^{\circ} \mathrm{N}-29.7^{\circ} \mathrm{E}\right)(55)$; I: VIII (45); M: (6.4) (45); AA: Iznik and its surroundings (2, 24, 55); Rel: 1-2.

Depending on the description given by Guidoboni et al. (1994), the waters of Lake İznik rose up.

28. 1 April 407: 5 July 408 (55), 20 April 417 (19); at night (24); SM; ER; I: VII-VIII (24); M: (6.6) (45); AA: Istanbul (2, 24); TI1: 3-4 (54); Rel: 2.

Many ships were wrecked, many corpses carried out to the coast of Hebdoman (Bakırköy-Istanbul) $(24,45)$. The Ottoman archives confirm that many ships sunk because of a tsunami caused by an earthquake (19).

29. 6 November 447: November $447(11,17,56), 8$ November 447 (2, 54), 8 December 447 (55), 447 (GITEC); 26 January 447 at night $(9,24,45)$; SM; ER; $\left(40.7^{\circ} \mathrm{N}-28.2^{\circ} \mathrm{E}\right)(4)$; I: IX-XI (24); M: 7.2 (15); AA: Istanbul, Gulf of Izmit, Marmara Islands, Sea of Marmara and Canakkale coasts $(2,9,15,24,45)$; TI1: 4(11), Istanbul 3 (11, 41, 44), Erdek Gulf 4, Marmara Islands 4- (44); Rel: 4.

The sea cast up dead fish; many islands were submerged; ships were stranded by the retreat of waters $(9$, $15,24,54)$. 
30. 25 September 478: 24/25/26 September 477/480 (2, 24); SM; EA; $\left(40.8^{\circ} \mathrm{N}-29.0^{\circ} \mathrm{E}\right)(55) ; I_{0}$ : IX (55); M: 7.3 (15); AA: Sea of Marmara, Yalova, Izmit, Hersek, Canakkale Region, Bozcaada (Tenedos), Istanbul (2, 15, 24, 55); Rel: 4.

In Istanbul the sea became very wild, rushed right in, engulfed a part of what had formerly been land, and destroyed several houses $(15,24,45)$.

31. 26 September 488: SM; EA; $\left(40.8^{\circ} \mathrm{N}-29.6^{\circ} \mathrm{E}\right)(55)$; $I_{0}$ : VIII (55); AA: Izmit Gulf $(2,56)$, Istanbul (55); Rel: 1.

It might be identical with 25 September 478 (55).

32. 524: 523-525 (24), 524/525 (2); EM; EA; $\left(37.2^{\circ} \mathrm{N}-\right.$ $35.9^{\circ}$ E) (55); $I_{0}$ : (VIII) (55); AA: Southern coasts of Anatolia, Anazarba-Adana (2, 55, 56); Rel: 1 .

33. 542: 16 August $542(24,45), 6$ September 542/543 (54), 16 August 541 (55); winter time $(54,56)$; SM; I: $\geq$ VIII (24); M: 6.8 (54), M: (6.5) (45); AA: West coasts of Thrace, Bandirma Gulf $(2,56)$, Edremit Gulf $(2,11$, 17); TI1: 4 (11, 54); Rel: 1.

34. 6 September 543: SM; ER; $\left(40.35^{\circ} \mathrm{N}-27.8^{\circ} \mathrm{E}\right)(55)$; $I_{0}$ : IX (55); M: (6.6) (45); AA: Kapıdağ Peninsula, Erdek, Bandirma (2, 6, 10, 21, 24, 41, 53, 55), Gulf of Edremit (56); TI1: 4 (54); Rel: 3.

Tsunami waves were reported $(6,24)$.

35. August 545: $543 \pm 1$ (33), 543 (65); BS; ER; $I_{0}$ : IX (33); M: $7.5 \pm 0.5$ (33); h: $20 \pm 10$ (33); AA: Thrace, vicinity of Varna $(24,33)$; TI1: 5 (33); TI2: $8-10$ (65); Wr: $\geq 2.0-4.0$ (33); Rel: 4.

Sea covered the territories of Varna and Balchik (33). In the year 544/545, the sea advanced in the territories of Odessa and Thrace, with a maximum inundation of $6 \mathrm{~km}$ on Thrace. Many were drowned in Odessa and Balchik (24). Many people were drowned by the waves along the Bosphorus shores (19). The accompanying earthquake may have been related to the one in BalcikBulgaria in 544/545 $(8,9)$.

36. January 549: SM; ER; AA: Istanbul; Rel: 2-3.

Massive waves were created by the earthquake and a huge fish (porphyrion) was thrown on shore $(9,19)$.

37. 9 July 551: EM; ER+EL; $34.0^{\circ} \mathrm{N}-35.5^{\circ} \mathrm{E}(52) ; I_{0}$ : IX$\mathrm{X}(52) ; \mathrm{M}_{\mathrm{S}}: 7.2$ (52); h: 28 (52); AA: Lebanese coast (24, 35, 52, 55); TI1: 5 (23), TI2: 8 (23); Rel: 4.

Tsunami along Lebanase coast $(24,35,52,55,67)$; in Botrys Mt. Lithoprosopon broke off and fell in to the sea, and formed a new harbour $(24,35)$; the sea retreated for a mile and then was restored to its original bed, many ships were destroyed $(24,35)$; the sea retreating by $1000 \mathrm{~m}$, tsunami waves destroyed many houses (54). Receding distance was $1800 \mathrm{~m}$ in Botrys $(24,35)$.

38. 15 August 553: 15 August $554(24,45)$; at night (24); SM; ER; $\left(40.75^{\circ} \mathrm{N}-29.10^{\circ} \mathrm{E}\right)(55) ; I_{0}: \mathrm{X}(55) ; \mathrm{M}:(7.0)$ (45); AA: Istanbul, Izmit Gulf $(2,24,55,56)$; Rel: 4.

Inundation distance about $3000 \mathrm{~m} \mathrm{(56).}$

39. 15 August 554: 554-558 (24), $554(21,53,55), 556$ (43), 558 (GITEC), August 556 (45); SA; ER; $36.8^{\circ} \mathrm{N}-$ $27.3^{\circ} \mathrm{E}(43,45)$; I: X (45); M: (7.0) (45); AA: The southwest coast of Anatolia, Kos Island, Gulf of Güllük (2, 10, 11, 17, 24, 41, 44, 45, 55, 56); TI1: 4 (54); Rel: 4.

The sea rose up to a fantastic height and engulfed all the buildings near shore in the Island of $\operatorname{Kos}(43,45)$; the sea receded at least $2 \mathrm{~km}$ and then flooded a 1-km-wide coastal area; many ships were wrecked; many sea animals and fish perished; waves were possibly observed on the Syrian coast (54).

40. 15 August 555: 15/16 August 555 (2, 18, 53, 56), 11 July 555 (24); SM; EA; AA: Istanbul, Izmit Gulf (2, 18, 21, 53, 56); Rel: 1.

41. 14 December 557: 14/23 December 557 (24) towards midnight (24, 55), 11 October/14 December 558 (54); SM; ER; $40.9^{\circ} \mathrm{N}-28.8^{\circ} \mathrm{E}(45,54)$; I: IX (45); M: (7.0) (45); AA: Lake Iznik region (9), Gulf of Izmit, Istanbul $(2,21,24,55,56)$; Many houses and churches were destroyed, particularly in the district Küçükçekmece (Regium, Rhegium or Rhegion) which was an outlying port of Istanbul (45); TI1: 4 (54); Rel: 4.

Inundation distance about $5000 \mathrm{~m}$ (56). Depending on recent archaeological findings this place should be the ancient Theodosian Harbour in Yenikap1, Istanbul.

42. 26 October 740: Early afternoon (24); 08.00 (55); SM; ER; $40.7^{\circ} \mathrm{N}-28.7^{\circ} \mathrm{E}(15,16)$; I: IX-XI (24); MS: 7.1 (16); AA: Sea of Marmara, Istanbul, Izmit, Iznik, southern coasts of Thrace, Mudanya (2, 9, 10, 11, 15, 17, 24, 26, 41, 55, 56); TI1: 3 (54), 4- (44); Rel: 4.

In some places, the sea receded from its shores, without returning to flood the coast $(15,24,45)$. The sea retreated behind its usual boundries and was intense enough to change the frontiers of some cities $(9,15)$.

43. 18 January 747: 18 January $749(23,24,67), 18$ January 743/745/746 (54); in the morning (24), 10:00 (23); EM; EA/EL; $32.50^{\circ} \mathrm{N}-35.60$ (52); $I_{0}$ : (IX) (55); $\mathrm{M}_{\mathrm{S}}$ : 7.2 (52); h: 25 (52); TI1: 5 (23), TI2: 8 (23); Rel: 4.

Waves were observed in Lebanon and Egypt (54); the sea boiled and overflowed and it destroyed most of the cities and villages along the coast (24); surface faulting 
and liquefaction in Mesopotamia, landslide at Mt. Tabor, many ships sank (52); a village near Mt. Tabor moved $6000 \mathrm{~m}$ from its orginal position; Moab fortress, then situated on the coast when the flood of the sea struck was uprooted from its foundations and set down $4500 \mathrm{~m}$ away (24).

44. 19 December 803: 803 (47); EM; AA: Gulf of Iskenderun $(2,17,56)$; TI1: 3 (11); Rel: 1.

45. 30 December 859: 8 April 859 (55), 8 April 85927 March 860 (24), 30 December 859-29 January 860 (52), November 859/861 (54), 859 (47); EM; EA/EL; $35.7^{\circ} \mathrm{N}-36.4^{\circ} \mathrm{E}(52) ; \quad I_{0}$ ： VIII-IX (52); $\mathrm{M}_{\mathrm{S}}$ : 7.4 (52); h: 33 (52); AA: Syrian coasts, Adana, Antakya, Samandağ, Akka (2, 17, 24, 54); Rel: 4.

A landslide on Mt. Casius, rocks fell into the sea (24); a part of Jabal Al-Akraa (Mt. Casius) was split and sank into the sea generating high waves (52); in the region of Samandağ the sea receded and then flooded the coast (54).

46. 25 October 989: 26 October $989(24,45)$, evening (24); 19:00 (16); SM; ER; $40.8^{\circ} \mathrm{N}-28.7^{\circ} \mathrm{E}(15,16)$; I: VIII (24); $\mathrm{M}_{\mathrm{S}}$ : 7.2 (16); AA: Istanbul, coasts of Sea of Marmara, Gulf of Izmit (2, 18, 21, 24, 56); Rel: 4.

The earthquake set up waves in the sea between the provinces of Thrace from Bythinia that reached into Istanbul $(9,15,18)$.

47. 5 April 991: in the night $(24,52)$; EM; EA/EL; $33.7^{\circ} \mathrm{N}-36.4^{\circ} \mathrm{E}(52) ; I_{0}$ : IX (52); $\mathrm{M}_{\mathrm{S}}$ : 7.1 (52), $\mathrm{M}_{\mathrm{L}}$ : 6.5 (67); h: 22 (52); AA: Damascus, Baalbek (24, 52, 55); Rel: 2-3.

Landslide; tsunami at Syria $(52,67)$.

48. 5 December 1033: 17 February 1033 (55), 4 January 1034, 6 March 1032, 1039, May 1035 (54); before sunset (25); EM; EA/ER; $32.4^{\circ} \mathrm{N}-35.5^{\circ} \mathrm{E}(23) ; I_{0}$ : IX (25); M: 6.9 (54); AA: Israel-Palestinian, Syria, Telaviv, Gaza with 70000 casualties $(25,55)$; TI1: 3 (23, 54), TI2: 5 (23); Rel: 4.

Tsunami and subsidence, a tsunami on the coast of Palestine, causing the water of Akka to recede at night $(23,25)$; tsunami at Balash (55); the sea port of Akka went dry for a long time, and then it was half destroyed by a wave (54).

49. 12 March 1036/11 March 1037: EM; EA/ER; AA: Cilicia (?), Southern Turkey; mountains were severely shaken and some landslides (25, 67); Rel: 2-3.

There was a strong tsunami in relation to this earthquake $(25,67)$.

50. 2 February 1039: January $1039(11,17,56)$, 2 January/February 1039 (54), 1 September 1038-31 August
1039 (25); SM; EA; $41.02^{\circ} \mathrm{N}-28.5^{\circ} \mathrm{E}(25)$; AA: Istanbul and other coastal region of the Sea of Marmara (2, 11, 17, 41, 56); TI1: 4 (54); Rel: 1.

51. 23 September 1064: 23 September $1063(16,25,45)$, 23 September 1065 (54); at night (25); 22:00 (16); SM; $\mathrm{ER} ; 40.8^{\circ} \mathrm{N}-27.4^{\circ} \mathrm{E}(16) ; I_{0}$ : (IX) (55); $\mathrm{M}_{\mathrm{S}}$ : 7.4 (16); AA: Iznik, Bandırma, Mürefte and Istanbul (2, 21, 55, 56); Rel: 1.

52. 29 May 1068: 18 March 1068/1067/1069 (54); 08:30 (23); EM; EA/ER; $32.0^{\circ} \mathrm{N}-34.83^{\circ} \mathrm{E}(23) ; I_{0}$ : IX (25); M: 7.0 (23); AA: Yavne-South Israel, Jerusalem, coast of Palestine (23, 25, 54); TI1: 4 (54), 5 (23), TI2: 8 (23); Rel: 3-4.

Tsunami in Holon, Ashdod and Yavne (23, 54); the sea retreated from the coast of Palestine, and then flowed back, engulfing many people, the banks of the river $\mathrm{Eu}-$ phrates overflowed $(25,54)$.

53. 20 November 1114: 1114 (54), 10 August 1114 (55), November 1114 (52, 67); EM; ER; $36.5^{\circ} \mathrm{N}-36.0^{\circ} \mathrm{E}$ (54); $I_{0}$ : VIII-IX (52); $\mathrm{M}_{\mathrm{S}}$ : 7.4 (52); h: 40 (52); AA: Ceyhan, Antakya, Maraş, Samandağ $(2,29,47,54,55)$; TI1: 3 (54); Rel: 2-3.

Landslide (52, 67); tsunami in Palestine (67).

54. 12 August 1157: 15 July $1157(2,55)$; EM; EA; $35.4^{\circ} \mathrm{N}-36.6^{\circ} \mathrm{E}(52) ; I_{0}$ : IX-X (52); $\mathrm{M}_{\mathrm{S}}$ : 7.4 (52); h: 15 (52); AA: Hama-Homs, Shaizar region $(2,55)$, Western Syria including Damascus (52); Rel: 1.

55. 29 June 1170: 03:45 (25); EM; ER; $34.4^{\circ} \mathrm{N}-35.8^{\circ} \mathrm{E}$ (55); $I_{0}: X(25)$; $\mathrm{M}_{\mathrm{S}}: 7.7$ (52); h: 35 (52); AA: Trablus, Antakya, Aleppo, Damascus region $(52,55)$, felt in Cyprus (55); Rel: 2.

Tsunami is reported without any location $(52,67)$.

56. 20 May 1202: 2 June 1201 (47), 21 May 1201 (23), early morning (52), 22 May 1202/1222 (54); EM; EA/ER; $33: 43^{\circ} \mathrm{N}-35.72^{\circ} \mathrm{E}(25) ; I_{0}: \mathrm{X}(25) ; \mathrm{M}_{\mathrm{S}}: 7.6$ (52); h: 30 (52); AA: Cyprus, Syrian coasts, Egypt, Nablus, Lebanon $(2,11,17,29,47,55,67)$; TI1: 5 (54), 4 (23), TI2: 7 (23); Rel: 4.

Damaging sea wave on Levantine coast (23); the sea withdrew from the coast, ships were hurled onto the eastern coast of Cyprus, fish were thrown onto the shore, and lighthouses were severely damaged (67); Paphos harbour in Cyprus dried (54).

57. 11 May 1222: 25 December $1222,06: 15(10,21)$, May 1222 (2, 10, 11, 17); EM; ER; $34.7^{\circ} \mathrm{N}-32.8^{\circ} \mathrm{E}(67)$; $I_{0}$ : IX $(25,55)$; M: 7.0-7.5 (67); AA: Baf, LimassolCyprus, Nicosia (2, 23, 55, 56, 67); TI1: 3 (23), TI2: 5 (23); Rel: 4. 
Tsunami flooding in Paphos and Limasol (23); the harbour at Paphos was left completely without water (25, $67)$.

58. 11 August 1265: 10/11/12 August 1265, at midnight (6); SM; EL; $40.7^{\circ} \mathrm{N}-27.4^{\circ} \mathrm{E}(6,45)$; I: VIII (13); M: (6.6) $(6,45)$; AA: Marmara Island $(6,25,45)$; Rel: 4.

A big piece of mountain breaks off and tumbles into the sea at Çınarlı, Marmara Island, creating huge waves that hit the shore and swallow up the area $(6,25,45)$.

59. 8 August 1303: 8/12 August 1303/1304 (54), August 1304 (44), 8 August 1304 (2, 41, 55); 03:30 (25), at 6 a.m. (43); SA; ER; $35.0^{\circ} \mathrm{N}-27.0^{\circ} \mathrm{E}(43) ; I_{0}: \mathrm{X}(25$, 43, 55, 67); M: 8.0 (43, 45, 54); AA: Crete, Peloponnesus, Dodecannesse Island, Rhodes, Antalya, Cyprus, Akka, Alexandria - Nile Delta, Lebanon, Palastine, Syria (23, 54, 67); TI1: 4 (54), 5 (43), TI2: 10 (43); Rel: 4.

Destructive inundation (43); the sea wave drowned many people and threw European ships on land (45); tsunami (25); landslide, the tsunami struck Crete, the coast of Egypt and part of Palestine, and fewer effects were observed in the Adriatic (67); in Egypt, ships sailing in the middle of the Nile and lying at anchor were thrown up into the banks $15 \mathrm{~m}$ inland (54).

60. 12 February 1332: 16 January 1332 (9, 19, 51), 12 February 1332/1331 (54), 17 January 1332 (25), 12 February 1331 (45); SM; ER; 40.9 $9^{\circ}-28.9^{\circ} \mathrm{E}(45,54)$; $I_{0}$ : VIII (45); M: $(6.8)(45,54)$; AA: Marmara Sea, Istanbul $(2,9,11,17,54,56)$; TI1: 3+ (54); Rel: 3 .

The waves beat the city walls of Istanbul, seriously damaging many of the dwellings therein (9); huge waves not necessarily of a tsunami but a by product of the storm in Istanbul (54); a large sea wave covered and destroyed the coastal walls of Byzantium up to their foundation (45).

61. 18 October 1343: 12 February 1331/1332/1334/ 1342/1343/1344 (54), 14 October 1344 (2, 10, 11, 17, $26,41,55,56), 1343.10 .18$ at 21:00 (16), 16:15 (25, 67); SM; ER; $40.9^{\circ} \mathrm{N}-28.0^{\circ} \mathrm{E}$ (16); I: VIII (45, 67); $\mathrm{M}_{\mathrm{S}}$ : 7.0 (16); AA: Sea of Marmara, Istanbul, Marmara Ereglisi (Heraclea), Gelibolu (2, 15, 16, 45, 54, 55); TI1: 4 (54); Rel: 4.

Huge waves flooded the shore of Thrace at a great distance, for a mile in some place (54). The sea rushed on land and plains, reaching up to $2000 \mathrm{~m}$. In some places it took off some ships at harbour and crushed them (9, $11,36,41,45)$; the large sea wave caused great destructions in Istanbul and in several other cities of Thrace in the Marmara (45); the sea receded, leaving mud and dead fish on land behind $(9,25,36,67)$; tsunami waves reached the Strait of Istanbul and affected Beylerbeyi $(9,36)$.

62. 20 March 1389: 12:30 (25); CA; ER; 38.4N-26.3E (45, 54); $I_{0}$ : VIII-IX (25, 67); M: 6.8 (54); AA: Izmir, Chios (2, 5, 10, 11, 17, 41, 44, 53, 55, 56, 67); TI1: 3 (54); Rel: 4.

Tsunami penetrated as far as the market place in Chios $(25,45)$. The waves caused destruction in İzmir and Yeni Foça (54).

63. 16 November 1403: $1402(21,26,55), 16$ November 1402/1403 (54), 18 December 1403 (25, 52); EM; ER; $I_{0}$ : (VIII) (55); AA: Aleppo $(25,52)$, southern coasts of Anatolia, Syrian coasts $(2,11,17,54,56)$; mountains collapsed (54); TI1: 3 (54); Rel: 4.

Near the shore of Syria and Palestine, the sea receded by more than one mile and then returned to its usual limits (54).

64. 20 February 1404: EM; EA+EL; $35.7^{\circ} \mathrm{N}-36.2^{\circ} \mathrm{E}$ (52); $I_{0}$ : VIII-IX (52); $\mathrm{M}_{\mathrm{S}}: 7.4$ (52); h: 30 (52); AA: Aleppo (52, 67); Rel: 2-3.

Landslide with damage in a few cities and tsunami in the Syrian coast (52).

65. 29 December 1408: 30 December 1408 (47), 1408 (23); EM; EA+EL; $35.8^{\circ} \mathrm{N}-36.1^{\circ} \mathrm{E}(52) ; I_{\max }: \mathrm{X}(25)$; $\mathrm{M}_{\mathrm{S}}$ : 7.4 (52); h: 25 (52); AA: Western Syria-Cyprus (67); TI1:3 (23), TI2: 5 (23); Rel: 3-4.

Landslide in Sfuhen and tsunami in Lattakia (52); tsunami threw the boats onto the shore $(25,67)$; strong tsunami in Syrian coasts (23); faulting between Sfuhen and Al-Quseir (52); faulting along at least $20 \mathrm{~km}$ from Quasr along Dead Sea Fault $(25,67)$.

66. 18 December 1419: 25 May 1419 (45), 19 December 1419/16 January 1420 (67); SM; ER; $40.9^{\circ} \mathrm{N}-28.9^{\circ} \mathrm{E}$ (45); M: (6.6) (45); AA: Istanbul (45); Rel: 2.

The earthquake caused tsunami (45); the sea became very rough and flooded the land, which was unusual (15).

67. 3 May 1481: 06:30 (25); SA; ER; $36.2^{\circ} \mathrm{N}-28.5^{\circ} \mathrm{E}$ (54); I: IX (45); M: 7.2 (45); AA: Rhodes, southwestern coasts of Anatolia, Crete (2, 25, 56); TI1:3 (54), TI2:8 (43); Wr: 1.8 (11, 41); Rp: 3 (43, 60); Rel: 4.

The largest shock accompanied by a sea wave of $3 \mathrm{~m}$ height $(43,45,54,60)$; the wave flooded the land and a ship in the harbour was whisked away, the damage done by the tsunami waves was greater than the damage caused by the earthquake $(45,54)$. In Rhodes the inundation distance was $60 \mathrm{~m}(11,41)$. 
68. 1489: 1481/1505-1510 (30); SA; ER; AA: Southern coasts of Anatolia, Antalya (2, 56); Rel: 2-3.

Submarine earthquake and strong withdrawal (43); the sea receded for three hours in Antalya (30); a tsunami was described by Leonardo da Vinci to have occured in 1489 in the sea of Antalya $(17,43)$

69. 1 July 1494: Evening time (41, 55); 10:10 (25); SA; ER; $35.5^{\circ} \mathrm{N}-25.5^{\circ} \mathrm{E}(54,55) ; I_{\max }$ : VIII-IX (25); M: 7.2 (54); AA: Heraklion-Crete $(2,11,17,25,44,55)$; TI1: 2+ (54); Rel: 4.

In the Candia (Heraklion) harbour, large waves caused violent collisions of anchored ships $(25,45,54)$; a withdrawal of the sea was observed in Israel (45).

70. 10 September 1509: 22:00 (14, 16); SM; ER; $40.75^{\circ} \mathrm{N}-29.0^{\circ} \mathrm{E}(55) ; I_{0}$ : IX (55); $\mathrm{M}_{\mathrm{S}}$ : 7.2 (16); AA: Istanbul and coasts of the Sea of Marmara $(2,10,11$, $17,21,26,38,41,44,53,55,56)$, felt over a large area from Bolu to Edirne with 4000-5000 casualties $(9,14)$; TI1: 3+ (44), 3- (54); Rp: $\geq 6.0$ (38); Rel: 4.

The shipyard in Izmit collapsed and waves flooded the dockyard $(9,14,38)$; In Istanbul tsunami waves overtopped the walls in Galata and flooded the districts of Yenikap1 and Aksaray $(2,9,38)$; depending on recent arkeological findings in Yenikapı the inundation distance in this region can be estimated as $500-600 \mathrm{~m}$ along the paleo-Lycus (Bayrampaşa) stream valley.

71. 29 September 1546: 14 January $1546(23,54)$; EM; EA; $32.0^{\circ} \mathrm{N}-35.1^{\circ} \mathrm{E}(23)$; I: VIII (23); M: 6.0 (23); AA: Nablus, Damascus, Jarusalem, Yafa, Tripoli, Famagusta (52); Israel and Palestine (23); Jerusalem, Damascus, Yafa, Sisem (61); TI1: 3+ (54), 5 (23), TI2: 8 (23); Rel: 4.

Tsunami at Cyprus (52); tsunami from Yafa to Gaza (23); many people were killed (61); after the storming sea had returned and rolled onto the coast, over 12,000 inhabitants of Gaza and Yafa were drowned (54); tsunami on the coasts of Cyprus and of Asia Minor (54).

72. 17 July 1577: 18:00 (14); SM; ER; AA: Istanbul (2, 14); Rel: 1.

Tremors in the sea, causing the sea to swell and engulf the galleys harboured therein (14).

73. 1598: BS; EA; $(40.4)^{\circ} \mathrm{N}-35.4^{\circ} \mathrm{E}(55) ; I_{0}$ : (IX) (55); AA: Amasya, Çorum (14); TI1: (4-5) (34), TI2: 2-4 (65); Wr: 1.0 (34); Rel: 4.

Tsunami waves at the coastal area between Sinop and Samsun due to the Amasya and Çorum earthquake (2, $8,34)$. The waves inundated about $1.6 \mathrm{~km}$ landward drowning a few thousand people living in the towns and villages (14).
74. April 1609: SA; ER; $36.4^{\circ} \mathrm{N}-28.4^{\circ} \mathrm{E}(45,54) ; I_{0}$ : IX (43); MS 7.2 (43); AA: Rhodes, Eastern Mediterranean, SE Aegean Sea (2, 14, 67); TI1: 4 (54), TI2: 8 (43); Rel: 4.

Over 10000 people were drowned by the waves (14); tsunami on the eastern part of Rhodes (54). Very strong waves observed in Rhodes and Dalaman $(43,67)$.

75. 8 November 1612: SA; ER; $35.5^{\circ} \mathrm{N}-25.5^{\circ} \mathrm{E}(54,55)$; $I_{0}$ : VIII $(55,67) ; \mathrm{M}_{\mathrm{S}}: 7.0$ (67); AA: Northern Crete (2, 10, 11, 17, 41, 44, 55, 67); TI1: 5- (54); Rel: 4.

Many ships sank in the harbour of Heraklion $(45,54)$.

76. 28 June 1648: 5 April 1641 (56), 5 April 1646 (2, 9, 54), 1646 (44), 21 June 1648 (14, 45), 28 June 1648, just before sunset (51); afternoon (55); SM; ER; $I_{0}$ : (VIII) (55); M: (6.4) (45); AA: Istanbul (2, 9, 10, 11, 14, 17, 26, 44, 55); TI1: 3 (54), 4- (44); Rel: 4.

The sea rushed onto the dry land destroying 136 ships $(54,56)$.

77. 29 September 1650: 9 October $1650(11,17,45), 29$ September 1650 (41, 44); SA; VO; 36.4 ${ }^{\circ} \mathrm{N}-25.4$ (44, 54); I: Santorini VIII; M: (7.0) (45); AA: Santorini, Patmos, Sikinos Islands, Northern Crete (2, 10, 11, 17, 41, $44)$; a strong underground volcanic eruption $(45,54)$; TI1; Sikinos 4+ (44), Heraklion 4 (41, 44); Wr: Western Patmos 30, Eastern Patmos 27, Ios 18 (11), Eastern Santorini 19, Patmos 30, Ios 18 (41); Rp:50 (GITEC); Rel: 4.

Inundation distances 200 and $100 \mathrm{~m}$ in Eastern Santorini and Sikinos, respectively (41). The generated sea wave reached a height of $30 \mathrm{~m}$ in the west coast of Patmos and $27 \mathrm{~m}$ in the east coast. In Sikinos, the sea entered 180 $\mathrm{m}$ inland. In Kea, ships drifted onto land and in Crete many ships broke from their anchorage (45).

78. 30 November 1667: 30 November 1667/10 July 1668 (54), 10 July 1668 (18, 21, 41, 56), November 1667 (55); CA; $38.4^{\circ} \mathrm{N}-27.1^{\circ} \mathrm{E}(54) ; I_{0}$ : (VIII) (55); M: 6.6 (54); AA: Izmir Gulf $(2,11,14,17,54,55,56)$; TI1: 2 (11, 41, 54); Rel: 1 .

The sea was stormy in Izmir (54).

79. 14 February 1672: April 1672 (53, 55), 1672 (17), $1672 / 1673$ the middle of April (54); NA; ER; $40.0^{\circ} \mathrm{N}-$ $26.0^{\circ} \mathrm{E}(54,55)$; I: IX (54); $\mathrm{M}_{\mathrm{S}}$ : 6.8 (67); AA: NE Aegean Sea, SE Aegean Sea (43, 67), Santorini, Cyclades, Bozcaada and Kos islands (2, 14, 17, 41, 43, 55), Cyclades and Santorini (17); Rel: 2.

Some houses in Bozcaada disappeared in waves (54); abnormal waves in Kos Island $(43,67)$; the island sank, no tsunami (11). 
80. 10 July 1688: 11.00 (55), 11.45 (14, GITEC); CA; ER; $38.4^{\circ} \mathrm{N}-26.9^{\circ} \mathrm{E}(54) ; I_{0}$ : X (55); M: 7.0 (54); AA: Izmir Gulf (2, 11, 14, 17, 44, 55); TI1: 3 (44), 2 (54); Rel: 2.

A weak tsunami was noted in Izmir (54). Ships in the harbour were disturbed (45).

81. 31 January 1741: $01: 15(14,43,45)$; SA; ER; $36.2^{\circ} \mathrm{N}-$ $28.5^{\circ} \mathrm{E}(43,45,54,67)$; I: Rhodes VIII (45); M: 7.3 (43, 45, 54); AA: Rhodes $(2,14,43,45,54)$; TI1: 5 (43), TI2: 8 (43); Rel: 4.

The sea retreated then flooded the coast of Rhodes 12 times with great violence $(2,14,43,45,67)$; the upper tsunami sediment layer found in Dalaman could be attributed to the 1741 tsunami $(43,67)$.

82. 14 March 1743: 8-20 March 1743 (14, 43); EM; ER; AA: Antalya, Rel: 2-3.

Sea withdrawal in Antalya $(43,67)$; the port dried up for some time $(14,43)$.

83. 15 August 1751: SM; ER; AA: Istanbul $(2,14)$; Rel: $1-$ 2.

An earthquake during a thunderstorm; ensuing flood caused considerable damage, carrying away 15 houses; might have been a minor submarine event causing abnormal waves (14).

84. 21 July 1752: EM; ER; $\left(35.6^{\circ} \mathrm{N}-35.75^{\circ}\right.$ E) (55); I: $X$ (23); $\mathrm{M}_{\mathrm{L}}$ : 7.0 (67); AA: Syrian coast (54); TI1: 3? (54), 2 (23), TI2: 3 (23); Rel: 3.

Tsunami at Syrian coasts $(2,11,17,21,23,52,55,67)$; harbour constructions in Syria suffered, possibly from the attack of tsunami waves (54).

85. 2 September 1754: 21:45 (55), 21:30 (16); SM; ER; $40.8^{\circ} \mathrm{N}-29.2^{\circ} \mathrm{E}(15,16) ; I_{0}$ : IX (55); $\mathrm{M}_{\mathrm{S}}$ : 6.8 (16); AA: Izmit Gulf and Istanbul $(2,14,15,55)$; Rel: 2-3.

In places the sea receded from the shore, presumably in Istanbul (15).

86. 30 October 1759: 03:45 (23, 52); EM; EA/EL; $33.1^{\circ} \mathrm{N}-35.6^{\circ} \mathrm{E}(23,52) ; I_{0}$ : VIII-IX (52); $M_{\mathrm{S}}: 6.6$ $(23,52)$; h: 20 (52); AA: Palestine and Lebanon (54); TI1: 3 (23), TI2: 5 (23); Rp: 2.5 (23); Rel: 4.

Landslides at the west of Damascus and Tabariya (52). Tsunami at Akka and Tripoli $(23,52)$.

87. 25 November 1759: 19:23 (23, 52); EM; EA/EL; $33.7^{\circ} \mathrm{N}-35.9^{\circ} \mathrm{E}(23,52)$; I: $\mathrm{X}(23) ; \mathrm{M}_{\mathrm{S}}$ : $7.4(23,52)$; h: 30 (52); AA: Bekaa-Syria, Antakya $(23,55)$, faulting along the Bekaa Valley (52); TI1: 4 (23), TI2: 7 (23); Rel: 4

Landslides near Mukhtara and Deir Marjijos (52); tsunami in Akka $(23,52)$.
88. 22 May 1766: 05:30 (14, 41, 55), 06:00 (51); SM; $\mathrm{ER} ; 40.8^{\circ} \mathrm{N}-29.0^{\circ} \mathrm{E}(15,16,54) ; I_{0}$ : IX (55); $\mathrm{M}_{\mathrm{S}}: 7.1$ (16); AA: Istanbul and Sea of Marmara $(2,11,14,17$, $41,53,54,55,56)$ causing 4000-5000 casualties and heavy damage extended over a large area from Izmit to Tekirdağ (14); TI1: 2 (11, 41, 54); Rel: 4.

Tsunami waves were recognized in the coastal village Beşiktaş-Istanbul and the inner parts of the Straits of Istanbul; uninhabited islets in the Sea of Marmara were said to have half-sunk into the sea. Izmit coasts were badly damaged by sea waves $(9,14,15)$; strong waves were particularly effective along the Bosphorus and in the Gulf of Mudanya (14).

89. 24 November 1772: 07:45 $(2,5,14)$; CA; ER; $38.8^{\circ} \mathrm{N}-$ $26.7^{\circ}$ E (45); I: Foça (VIII) (45); M: (6.4) (45); AA: Chios Island and Foça $(2,5,14)$; Rel: 3 .

The gates of Foça Castle, which were on the edge of the sea, were completely destroyed by the earthquake and tsunami (14).

90. 13 August 1822: 21:50 (52), 20:00 (28); EM; EA; $36.1^{\circ} \mathrm{N}-36.75^{\circ} \mathrm{E}(52) ; I_{0}$ : IX (52); $\mathrm{M}_{\mathrm{S}}: 7.0$ (52); h: 18 (52); AA: Antakya, Iskenderun, Kilis and Latakia (28, 55) with 20000 casualties (52, 55); TI1: 3 (54); Rel: 4.

Faulting and tsunami in Beirut (52); tsunami in Beirut, Iskenderun, Cyprus and Jerussalem $(54,67)$.

91. 23 May 1829: 5 May 1829, 09:00 (45); SM; ER/EA; I: Drama X (45); M: $7.3(45,54) ; A A:$ AA: Istanbul, Gelibolu (2, 55, 56); TI1: $2(11,54)$; Rel: 1.

Tsunami in Istanbul $(2,10,17,28,55,56)$; a spurious event (15); two shocks in Istanbul, buildings damaged on the Asiatic coast (28). An unusual roughness in the sea was observed (54).

92. 1 January 1837: 03:00 (28, 55), 16:00 (52); EM; EA/ER; $\left(32.9^{\circ} \mathrm{N}-35.4^{\circ} \mathrm{E}\right)(55) ; I_{0}$ : VIII (52); $\mathrm{M}_{\mathrm{S}}$ : $>7.0$ (52); AA: Israel and Syria (23) with 5000 casualties $(28,55)$; Rel: 3 .

Tsunami on the coasts of Israel and Syria (23); tsunami in Lake Tabariya $(28,52)$.

93. 18 October 1843: SA; ER; $36.3^{\circ} \mathrm{N}-27.7^{\circ} \mathrm{E}(45) ; I_{0}$ : IX (55); M: 6.5 (44, 54); AA: Chalki and Rhodes Islands, 6000 dead (55); Rel: 3.

Chalki, tsunami was observed (54). Ships overturned and a mountain collapsed (45).

94. 25 July 1846: 17:30: CA; ER; AA: Izmir, Aegean Sea (54); TI1: 3? (54); Rel: 1 .

The sea was very turbulant during fine weather (54).

95. 28 February 1851: 15:00 (43, 45, GITEC), 02:58 (54); $\mathrm{SA} ; \mathrm{ER} ; 36.4^{\circ} \mathrm{N}-28.7^{\circ} \mathrm{E}(67) ; I_{0}$ : IX $(55,67) ; \mathrm{M}_{\mathrm{S}}$ : 7.1 
(67); AA: Fethiye, Kaya-Muğla, Rhodes $(2,11,17,28$, 41, 44, 53, 55, 56, 67); TI1: 3 (11, 41, 54); Rp: 0.6; Rel: 4.

Tsunami in Fethiye $(43,67)$; a subsidence on the Fethiye coast and landslides from the Muğla mountainsides (45). The sea in Fethiye rose approximately $34 \mathrm{~cm}$. The shore in Fethiye sunk $0.5 \mathrm{~m}$ (54); the coast was flooded about $0.6 \mathrm{~m}$ above the normal sea level at Fethiye $(43,67)$.

96. 3 April 1851: 3/23 April/May 1851 (54); 17:00 (54); SA; ER; $36.4^{\circ} \mathrm{N}-28.7^{\circ} \mathrm{E}(43,67)$; AA: Gulf of Fethiye (2, 11, 17, 41, 56, 67), Rhodes (54); TI1: 3 (54); Rp: 1.8; Rel: 4.

Tsunami in Fethiye $(43,67)$. The sea rose many meters higher than its level and flooded the coast (54). This event was possibly an aftershock of the 1851.02.28 earthquake; the run-up was $1.8 \mathrm{~m}$ in the Fethiye region $(43,67)$.

97. 23 May 1851: 23 April/May 1851 (54); SA; ER; $36.4^{\circ} \mathrm{N}-28.7^{\circ} \mathrm{E}(43,67)$; AA: AA: Rhodes, Dodecanese Islands and Chalki $(2,11,17,41,43,54,56$, $67)$; possibly an aftershock of the event of 28 February 1851; TI1: 2 (11, 41, 54); Rel: 2.

Tsunami waves observed in Rhodes and Chalki, but the reported inundation distances are doubtful $(43,67)$.

98. 12 May 1852: 5/12 May 1852, 02:00 (54); CA; ES; TI1: 2-3 (54), 3 (11, 41); Rel: 1-2.

The day before the earthquake occurred in Izmir $(2,11$, $17,28,41,54)$ the sea receded leaving the sea bottom dry for a distance of many yards (54). Rather strong tsunami at Izmir (28).

99. 8 September 1852: 22:30 (54); CA; AA: Izmir (2, 11, 17, 28, 41, 56), Fethiye Gulf (56); TI1: 3 (54); Rel: 1-2.

Rather strong tsunami at Izmir (28); the sea rose, though no slightest breath of wind was to be felt before (54).

100. 13 February 1855: 9/10/13 February 1855 (21, 29), 2 March 1855 (28, 55), 9-13 February 1855 (56); EM; ER; AA: Chios Island (56), Fethiye Gulf $(2,11,17,21$, 29, 41); Rel: 2.

Tsunami waves in Fethiye with doubtful inundation (43, 67). Depending on the definitions given by Karnik (1971), a 32-m-wide coastal strip in Fethiye sank into the sea.

101. 12 October 1856: 00:45 (55), 02:45 (45); CA/SA; ER; $\left(35.5^{\circ} \mathrm{N}-26.0^{\circ} \mathrm{E}\right)(28,54)$; I: Heraklion IX (45); M: 8.2 (45); AA: Crete and Heraklion $(45,54)$, Rhodes, Crete, Chios, Karpatos (55); TI1: 3+ (54); Rel: 2-3.

A tsunami was generated (54).
102. 13 November 1856: 13 December 1856 (56); CA; ER; $38.25^{\circ} \mathrm{N}-26.25^{\circ} \mathrm{E}(55) ; I_{0}$ : VIII $(5) ;$ M: $6.6(44,54)$; AA: Chios Island $(2,5,11,17,28,41,44,45,53,54)$, Rhodes (55); TI1: 3+ (54); Rel: 4.

A large tsunami wave was observed (54); the sea rushed on the land and some people were lost in Chios $(5,45)$.

103. 17 September 1857: 22:00 (28, 54); SM; ER+EL; AA: Istanbul (54); Rel: 1.

Houses on the seashore and the cellar of a brewery at Kuruçeşme, Bosphorus, were flooded by seawater, a consequence of local land subsidence (54).

104. 21 August 1859: $02: 00(45,55), 11: 55(28,54), 11: 30$ (16); NA; ER; $40.3^{\circ} \mathrm{N}-26.1^{\circ} \mathrm{E}(15,16) ; I_{0}$ : IX (55); $\mathrm{M}_{\mathrm{S}}$ : $6.8(15,16)$; AA: Gökçeada (Imbros) Island (45, 54, 55), felt at Enez, Edirne, Istanbul and Gelibolu (28); TI1:3 (54); Rel: 1-2.

Some sailors at sea reported the disappearance of Gökçeada for a moment. The sea waves observed at the northern approaches of the Strait of Istanbul could not be related with this event (15).

105. 22 March 1863: 22 April 1863, 20:30 (28, 55), 22 April 1863, 21:30 (45); $22: 15$ (54); SA; ER; $36.5^{\circ} \mathrm{N}-28.0^{\circ} \mathrm{E}$ $(28,54,55)$; I: Rhodes X (45); M: 7.8 (45); AA: Rhodes (45, 54); Rel: 2-3.

The earthquake gave rise to a terrible storm at the sea which resulted in many accidents, several calamities occurred on the Mersin roadstead, the sea near Tripoli (Lebanon) was furrowed by huge waves at midday of 22 March (54).

106. 19 January 1866: $12: 30(5,54)$; CA; ER; $38.25^{\circ} \mathrm{N}-$ $26.2^{\circ} \mathrm{E}(55) ; I_{0}$ : VII $(54,55)$; M: 6.8 (54); AA: Chios island (5, 54); Rel: 2.

Intensive boiling of the sea water was noticed approximately in the middle of the Cesme strait, oscillations of the level were observed (54).

107. 31 January 1866: 28/31 January 1866 (54); at night (45); SA; ER; $36.4^{\circ} \mathrm{N}-25.4^{\circ} \mathrm{E}$ (44, 45); $I_{0}$ : (VIII) (55); M: 6.1 (28); AA: Santorini Island (2, 28, 44, 45, 54, 55); TI1: Santorini 4, Kythera 3, Chios 3 (44); Rel: 1-2.

The sea started to hit the coastal houses causing cracks and submersions (45); some other sources indicate that no tsunami occurred (54).

108. 2 February 1866: CA; ER; $38.25^{\circ} \mathrm{N}-26.25^{\circ} \mathrm{E}(28$, 55); $I_{0}$ : VIII (55); M: (6.4) (45); AA: Chios Island (2, 11, 17, 21, 28, 55); TI1: 3 (11, 54); Rel: 2.

Tsunami in Chios (28, 54, GITEC). This earthquake was preceded by a strong shock on 19 January (45). 
109. 7 March 1867: 06:00 (55), 16:00 (28), 18:00 (45, 54); CA; ER; $39.1^{\circ} \mathrm{N}-26.6^{\circ} \mathrm{E}(54)$; I: (X) (45); M: 6.8 (45); AA: Lesvos Island $(45,54,55)$, at Mitilini more than 500 casualties $(28,55)$; TI1: 2 (54); Rel: 4.

After the earthquake dead fish were found inside a boat in the Mitilini harbour, the low-lying lands of Mitilini were flooded after the earthquake $(45,54)$.

110. 3 April 1872: 2 April 1872, 07:45 (55), 07:40 (23); EM; $\mathrm{EA} ; 36.25^{\circ} \mathrm{N}-(36.10)^{\circ} \mathrm{E}(55) ; I_{0}$ : (IX) (55); $\mathrm{M}_{\mathrm{S}}: 7.2$ (23, 67), $\mathrm{M}_{\mathrm{S}}: 5.9$ (52); h: 10 (52); AA: Antakya, Samandağ (55), Amik Lake (23); faulting at Baghras, liquefaction (52); TI1: 3 (23), TI2: 6 (23); Rel: 4.

Tsunami waves flooded the Samandağ (Suaidiya) coast (23).

111. 19 April 1878: 09.00 (55); SM; EA/ER; $40.7^{\circ} \mathrm{N}-$ $30.2^{\circ}$ E (15); I: IX (54); M: 5.9 (15); AA: Izmit (2, 10, 11, 15, 17, 28, 55, 56), Istanbul, Bursa, Sapanca (55); TI1: 3 (11, 54); Rel: 4.

In the Gulf of Izmit the shock set up a small tsunami which propagated into the west of the Gulf where the earthquake was also felt on board of ships, causing some concern (15). A rather strong tsunami was supposedly observed in Izmit (54).

112. 3 April 1881: $11: 30(28,55)$; CA; ER; $38.3^{\circ} \mathrm{N}-26.2^{\circ} \mathrm{E}$ (5); I: Chios IX $(5,45) ; \mathrm{M}: 6.5(5,45) ; \mathrm{AA}$ : Chios Island and Çesme $(5,55)$ with 4000 casualties; TI1: $2+(54)$; Rel: 3 .

On 5 April at 03:10 a.m. a strong vertical shock demolished some city walls. The sea became wavy right away and a mass of smoke was seen rising from sea surface. The aftershocks created waves on the sea surface (5).

113. 9 February 1893: 28 January $1893(21,55), 9$ February 1893/28 January 1893 (54); 18:00 (41, 45, 55), 17:16 (16); NA; ER; $40.5^{\circ} \mathrm{N}-26.2^{\circ} \mathrm{E}(15 ; 16) ; I_{0}$ : IX (55); MS: $6.9(15,16)$; AA: Northern Aegean Sea, Samothrace Island, Thracian coasts, Alexandroupolis (2, 10, 11, 17, 21, 28, 41, 44, 55); TI1: Alexandroupolis 3 (11, 41, 44); Wr: Samothrace 0.9 (11, 41), Alexandroupolis 0.9 (41), Islet Aghistro and Alexandroupolis 1.0 (28, 54); Rp: 1.0, Saros (15); Rel: 4.

Tsunami at Thracian coasts (55); the water rose by $1 \mathrm{~m}$ near Islet Aghistro and entered the land in a distence of 25-30 $\mathrm{m}$ and $40 \mathrm{~m}$ in Aghistro and Alexandroupolis, respectively $(28,41,45,54)$; tsunami flooded the coast on Samothrace and the mainland in Thrace about $15 \mathrm{~min}$ after the main shock (15).

114. 10 July 1894: 12:24 (16), 12:30 (55), 12:33 (28, GITEC); SM; ER; $40.6^{\circ} \mathrm{N}-28.7^{\circ} \mathrm{E}(28,54) ; I_{0}$ : (X) (55); $\mathrm{M}_{\mathrm{S}}: 7.3$ (16); AA: Istanbul $(2,11,17,22,28,29$, 38, 39, 41, 44, 55), Izmit (15), Karamürsel, Adapazari,
Prince Islands off the coast of Istanbul (55); 474 casualties in Istanbul (9, 39); TI1: 3 (54); Wr: $\leq 6.0$ (38); Rp: $1.5 \mathrm{~m}$ in Yeşilköy (San Stefano), $4.5 \mathrm{~m}$ at the Azapkap1 Bridge (9, 15); Rel: 4.

Tsunami occurred with a receding distance of $50 \mathrm{~m}$ and a maximum inundation distance of $200 \mathrm{~m}$ between Büyükçekmece and $\operatorname{Kartal}(2,39)$.

115. 31 March 1901: $\mathrm{BS} ; \mathrm{EL} ; 43.4^{\circ} \mathrm{N}-28.5^{\circ} \mathrm{E}$ (GITEC); $I_{0}$ : X (GITEC); AA: Balchik, Bulgaria (27); Wr: 3.0 (20); Rel: 4.

At Balchik boats uplifted (GITEC) and landslide occurred (27). The coastal area $\left(0.2 \mathrm{~km}^{2}\right)$ at Keçikaya District subsided (27). A three-meter-high tsunami washed away the port of Balchik (20).

116. 9 August 1912: 01:29 UTH (4), 01:28 (16); SM; ES; $40.75^{\circ} \mathrm{N}-27.2^{\circ} \mathrm{E}$ (EMSC) I: X (12); $\mathrm{M}_{\mathrm{S}}: 7.3$ (12, 15, 16, KOERI); h: 16 (4); AA: Şarköy, Mürefte, Istanbul (4), Ganos (15) with 2800 casualties (12); TI1: 3-4; Rp: Yeşilköy 2.7 (4); Rel: 4.

A high water occurred within the Bosphorus, demolishing a yacht named "Mahrussa" anchored at Paşabahçe (4); the sea receded along the Tekirdağ shores (12). The ships anchored offshore Yeşilköy were aground with the recede of the sea after the earthquake and then the sea lifted the fishery boats up to a height of $2.7 \mathrm{~m}$ (4).

117. 31 March 1928: 00:29:47 (2, 28, 41): CA; EA; $\left(38.2^{\circ} \mathrm{N}-27.4^{\circ} \mathrm{E}\right)(\mathrm{EMSC}) ; I_{0}$ : IX (28); $\mathrm{M}_{\mathrm{S}}: 6.5$ (54, KOERI); AA: Izmir (2, 11, 17, 28, 41, 54); TI1: 2 (54); Wr: 0.5 (54); Rel: 2.

A weak tsunami (54).

118. 23 April 1933: 05:57:37 (45), 05:58 (54); SA; ER; $36.8^{\circ} \mathrm{N}-27.3^{\circ} \mathrm{E}(45) ; I_{0}$ : IX (28); M: $6.6(45) ; \mathrm{h}: 50$ $(28,54)$; AA: Kos Island and Nisyros $(45,54)$; TI1: 2 (54); Rel: 2.

An earthquake and tsunami took place (54).

119. 4 January 1935: 14:41:29 UTH (6), 14:41:30.4 (KOERI), 16:41:29 (6); SM; ER+EL; $40.64^{\circ} \mathrm{N}-27.51^{\circ} \mathrm{E}$ (6); $I_{0}$ : IX (6); $\mathrm{M}_{\mathrm{S}}$ : 6.4 (6); h: 30 (KOERI); AA: The villages of Marmara Island were totally destroyed; strongly felt in Istanbul, Tekirdağ, Edirne, Izmir and Bursa (6); TI1: 2-3; Rel: 4.

The Hayırsiz Island collapsed on three sides causing a local tsunami (6).

120. 26 December 1939: 23:57:16 (2); BS; EA; $39.7^{\circ} \mathrm{N}$ $39.7^{\circ} \mathrm{E}(2)$; I: XI (2); MS 8.0 (2); h: 20 (KOERI); AA: Erzincan (33, 65); TI1: 4 (33), TI2: 3-5 (65); Wr: 1.0 (33); Rel: 4.

Fatsa; extraordinary sea disturbances were seen at the time of the $\mathrm{Ms}=8.0$ Erzincan earthquake (2, 8, 33, 
46, 65). The sea receded in Fatsa about $50 \mathrm{~m}$ and then advanced $20 \mathrm{~m}$. In Ünye the sea receded about $100 \mathrm{~m}$ causing some sunken rocks to appear for the first time. The sea also receded in Ordu by about $15 \mathrm{~m}$ and then returned back. The initial rise of the sea level was recorded at 6 tidal stations (Tuapse, Novorossiyk, Kerch, Feodosia, Yalta, and Sevastopol) on the northern coast of the Black Sea (32).

121. 20 January 1941: 03:37 (23); EM; ER; $35.0^{\circ} \mathrm{N}-$ $34.0^{\circ} \mathrm{E}(28) ; I_{\max }$ : IX (28); $\mathrm{M}_{\mathrm{S}}$ : 5.9 (23); AA: Cyprus and Ammochostos (23); TI1: 2 (23), TI2: 3 (23); Rel: 2.

Small tsunami on Palestine coast (23).

122. 6 October 1944: 02:34:48.7 (7); CA; ER; $39.48^{\circ} \mathrm{N}-$ $26.56^{\circ} \mathrm{E}(7) ; I_{0}$ : IX (7); $\mathrm{M}_{\mathrm{S}}: 6.8$ (7); h: 20 (EMSC); AA: Earthquake in Ayvacık and Edremit Gulf with 30 casualties and 5500 damaged/destroyed houses (7); TI1: 4; Rel: 4.

Numerous surface cracks and water gushes reported; coastal neighborhoods of the town of Ayvalık were flooded; inundation distance was $200 \mathrm{~m}$ in Ayvalık (7).

123. 9 February 1948: $12: 58: 13$ (2, 41, 43, 45, 67); SA; ER; $35.51^{\circ} \mathrm{N}-27.21^{\circ} \mathrm{E} ; I_{0}$ : IX (67); $\mathrm{M}_{\mathrm{S}}$ : 7.1 (67); h: 40 (EMSC); AA: Karpathos-Dodecanese (2, 11, 17, 31, 41, 42, 44); TI1: 4 (43, 54), TI2: 7 (43); Rp: 2.5; Rel: 4.

Damaging waves in Karpathos (43, 67, GITEC); a destructive tsunami originated and rolled along the eastern shore of the Island of Karpathos (54); tsunami caused damage $\mathrm{n}$ the southwest coast of Rhodes (45); the first tsunami wave followed about 5-10 min after the earthquake, many vessels were cast ashore and destroyed $(43,67)$; the 1948 wave pentrated inland about $250 \mathrm{~m}$ leaving scores of fish behind to a distance of about $200 \mathrm{~m}$ from the shore line (43); the first motion of the sea was withdrawal $(43,67)$; inundation distance of $900 \mathrm{~m}(11,41,42)$; inundation distance of $1000 \mathrm{~m}$ near Pigadia $(45,54)$.

124. 23 July 1949: 15:03:30 (42), 15:03:33.2 (KOERI); CA; ER; $38.58^{\circ} \mathrm{N}-26.23^{\circ} \mathrm{E}(5,45) ; I_{0}$ : IX $(5,45) ; \mathrm{M}: 6.7$ $(5,45)$; h: 10 (KOERI); AA: East Aegean Sea, North Chios Island (2, 42, GITEC); TI1: 2 (54); Wr: 0.7/2.0 (2, 42); Rel: 4.

In Chios, the port sank $0.35 \mathrm{~m}$; the sea attacked the coast of Cesme town, leaving many dead fish behind after it retreated (5).

125. 10 September 1953: 04:06 (54), 04:06:09 (23); EM; ER; $34.76^{\circ} \mathrm{N}-32.41^{\circ} \mathrm{E}$; I: X (54); M: 6.2 (40); h: 30 (KOERI); AA: South coasts of Turkey $(2,31)$ and Paphos (23); TI1: 2-3 (54), 2 (23), TI2: 3 (23); Rel: 3-4.

Series of tsunami waves were noted on the Island of Cyprus (54); small tsunami wave along the coast of Paphos (23).
126. 9 July 1956: 03:11:40 (41, 42, 45, 67); SA; ER; $36.69^{\circ} \mathrm{N}-25.92^{\circ} \mathrm{E}$ (KOERI); $I_{0}$ : IX (67); $\mathrm{M}_{\mathrm{S}}$ : 7.5 (67); h:10 (KOERI); AA: Greek Archipelago, Amargos, Astypalaea Islands, Fethiye (2, 11, 17, 31, 41, 42, 66); 03:12 and 05:24, event associated with two shocks (54); TI1: Amargos 6 (41), Astypalaea 6 (42); Wr: Amorgos 30 (11), 20-25 (41, 42); 30 (11), Astypalaea 20 (11, 41, 42), Pholegandros $10(11,41)$, Patmos 4, Kalimnos 3.6, Crete 3, Tinos 3 (11), $\geq 5$ (41), Fethiye 1 (66); Rel: 4.

Huge waves flooded the fields in the islands. The sea rose up $1 \mathrm{~m}$ and a recorded inundation distance of $250 \mathrm{~m}$ in Fethiye (66); inundation distance at Amargos 80$100 \mathrm{~m}(41,42)$; at Astypalaea $400 \mathrm{~m}(41,42)$; at Pholegandros $8 \mathrm{~m}$ (41), at Tinos $\geq 700 \mathrm{~m} \mathrm{(41).}$

127. 23 May 1961: 02:45:20 (45), 02:45:22 (KOERI); SA; ER; $36.6^{\circ} \mathrm{N}-28.3^{\circ} \mathrm{E}$ (EMSC); I: Rhodes (VII) (45); h: 72 (EMSC); AA: Marmaris, Fethiye, Rhodes, Izmir, Aegean Sea (45, 54, 59); TI1: 3 (54); Rel: 2.

A weak wave, the color of the water in the Gulf of Izmir changed after the earthquake and it was filled with algae (54); the sea colour turned red in Fethiye and Izmir after the earthquake (59).

128. 18 September 1963: 16:58:14.8 (2, 37); SM; ER; $40.64^{\circ} \mathrm{N}-29.13^{\circ} \mathrm{E} ; I_{0}$ : VIII (37); $\mathrm{M}_{\mathrm{S}}$ : 6.3 (2, KOERI); h: 40 (EMSC); AA: Eastern Marmara, Yalova-Çınarcık, Karamürsel, Kılıç, Armutlu, Mudanya, Gemlik Gulf (2, 29, 37); Rp: 1.0 (2, 29); Rel: 4.

Along the coast of Mudanya a strip of sea shells and molluscs was observed and waves reached a height of $1 \mathrm{~m}(2,29,37)$.

129. 19 February 1968: 22:45:42 (41, 45), 22:57:47 (42); NA; ER; $39.4^{\circ} \mathrm{N}-24.9^{\circ} \mathrm{E}(54)$; I: Aghios Eustrations IX (45); M: 7.1 (45); AA: North Aegean Sea (2, 17, 31); TI1: 2 (41), 3 (54); Wr: 1.2 in Mirina (41, 45, 54); Rel: 4.

A small tsunami originated on the western (54) and southern (45) shore of the Island of Lemnos; the sea penetrated on land by $20 \mathrm{~m}$ in Moudros and $4 \mathrm{~m}$ in Kaspakas $(45,54)$.

130. 3 September 1968: 08:19:52.6 (2); BS; ER; $41.78^{\circ} \mathrm{N}-$ $32.43^{\circ} \mathrm{E}(1) ; I_{0}$ : VIII (1); $\mathrm{M}_{\mathrm{S}}$ : $6.6(1)$; h: 4 (1); AA: Bartın and Amasra (1); TI1: 3+ (33), TI2: 3-5 (65); Wr: 3.0 (48); Rel: 4.

The Bartın earthquake exhibited the first known seismological evidence of thrust faulting along the southern margin of the Black Sea (1). The coastal hills between Çakraz and Amasra were uplifted. The sea receded 12$15 \mathrm{~m}$ in Çakraz and never returned entirely to its original level (29). The sea inundated $100 \mathrm{~m}$ in Amasra and after $14 \mathrm{~min}$ the second wave inundated the shore about $50-60 \mathrm{~m}$ (62). The reason for this progression was most 
probably the uplifting around Çakraz $(2,8,65)$. The sea rose about $3 \mathrm{~m}$ in Amasra (48).

131. 6 August 1983: 15:43:51.9 (KOERI); 15:43 (45); NA; ER; $40.0^{\circ} \mathrm{N}-24.7^{\circ} \mathrm{E}$ (45); I: Aghios Dimitrios VI (45); M: 6.8 (45); h: 10 (EMSC); AA: Lemnos Island (45); TI1: 2+ (54); Rel: 3-4.

Tsunami on Lemnos Island (54); light tsunami waves in Mirina of Lemnos (54).

132. 4 January 1991: CA; ER; $37.7^{\circ} \mathrm{N}-26.3^{\circ} \mathrm{E}$; AA: Ikaria Island (54); TI1: 2; Rel: 1.

Weak local sea waves in Ikaria Island; possibly of meteorological origin (54).

133. 7 May 1991: CA; ER; 37.1N-26.8E; AA: Leros Island (54); TI1: 3; Wr: 0.5; Rel: 1.

Sudden and intense rise of the sea level by $0.5 \mathrm{~m}$ in Leros Island; possibly of meteorological origin (54).

134. 17 August 1999: 00:01:38.6 (KOERI); SM; EA+EL; $40.73^{\circ} \mathrm{N}-29.88^{\circ} \mathrm{E} ; \mathrm{M}_{\mathrm{W}}: 7.4(2,3,50,58,63,64)$; h: 18 (2); AA: A very strong earthquake with at least 18850 casualties in the Gulf of Izmit was felt over a very large area (9). The earthquake produced at least $120 \mathrm{~km}$ of surface rupture and right lateral offsets as large as $4.2 \mathrm{~m}$ with an average of $2.7 \mathrm{~m}(3,9)$; TI1: 3; Wr: Değirmendere $\geq 12$ (3); Rp: Değirmendere $4 \mathrm{~m}$ (50), Yarımca $3.2 \mathrm{~m}$ (58), generally between $1-2.5 \mathrm{~m} \mathrm{(2,}$ 3); Rel: 4.

The runups are more complex along the south coast due to the presence of coastal landslides $(2,3,9,50,63,64)$. The period of tsunami was less than 1 min (63). The inundation distance in Kavaklı was more than 300 m (3).

\section{Results and discussion}

Throughout the course of time, Turkish coasts have been affected by catastrophic tsunamis (Soysal et al., 1981; Soysal, 1985; Kuran and Yalçıner, 1993; Altinok and Ersoy, 2000). In this paper, all of the known tsunami events were critically examined and re-evaluated in terms of their causes and source codes. The codes include tsunami intensities (Sieberg-Ambraseys and Papadopoulos-Imamura scales), water level rise, run-up and reliability. The obtained current version of the database contains the data on 134 tsunamigenic events over a span of 3500 years.

At least 76 of the events listed in the revised database above were found to be reliable ones, with a reliability of 3 and 4. Most of the events took place in the Aegean Sea (51), Eastern Mediterranean (41) and in the Sea of Marmara (35). The majority were caused by strong earthquakes mainly occurring in the sea and in most of the cases, the affected coastal areas were less than $200 \mathrm{~km}$ far from the tsunami source.



Fig. 2. Distribution of submarine canyons and scars of landslides superimposed on the shaded bathymetry of the Sea of Marmara which is drawn from the multibeam data seta of French institute IFREMER (Rangin et al., 2001) and Turkish Navy Department SHOD. The bathymetric data in the shelf is from navigation charts, so data grid is relatively scarce. Gridding and mapping of the data were obtained by means of Generic Mapping Tools (Wessel and Smith, 1998). Active fault traces are based on previous studies by Le Pichon et al. (2001) and Yaltırak (2002). Slides: GC (Ganos complex), MI (Marmara Island) and TC (Tuzla complex).

The recurrence interval of the Black Sea tsunamis is on the order of 10 to 120 years and their run-ups measured by tide gauges are not very high (Ranguelov, 1996b; $<1 \mathrm{~m}$; Yalçıner et al., 2004; Dotsenko and Eremeev, 2008). Although the Black Sea tsunamis are mostly regional and affect the nearest coast, our database shows that the Black Sea may be subject to some destructive tsunamis with large run-ups and inundation distances (e.g. 1598 event). The quiescense period may be followed by bigger effects and the fact that there are no reported big tsunamis in the near past does not show that this phonemenon is not dangerous for the coastal communities (Ranguelov and Gospodinov, 1995). The mean repeatability of the tsunamis exceeding $5 \mathrm{~m}$ is more than 1000 years for Black Sea (Ranguelov, 1997, 2003). The main tsunami sources in the Black Sea are the faults in the sea or other secondary mechanisms on the coast which can be triggered by a far-offset main shock with an epicenter on land, as in the case of the 1939 event. Although there is still some debate the possibility of submarine landslides should be considered in the Black Sea (Ranguelov et al., 2008; Vilibić et al., 2010).

Most of the large and destructive tsunamis were generated by submarine earthquakes in the Mediterranean region (SA and EM). The Aegean Arc introduces the highest tsunami potential as some infrequent but large events have been recognized in the South Aegean region where shallow and intermediate depth earthquakes possess magnitudes that exceed 7. Landslides have also locally generated some powerful tsunamis and volcanic eruptions are also important in the Southern Aegean region. The first event in the tsunami catalogues was generated by the eruption of the Santorini volcano and accompanying earthquakes. Significant stratified 
Table 1. Some of the most detailed tsunamigenic event sources.

\begin{tabular}{|c|c|c|c|c|c|c|c|c|c|c|c|c|c|}
\hline Date & $\begin{array}{l}\text { Source } \\
\text { name }\end{array}$ & $\begin{array}{c}\text { Fault } \\
\text { type }\end{array}$ & $\begin{array}{l}\text { Sub- } \\
\text { region }\end{array}$ & $\begin{array}{l}\text { Length } \\
(\mathrm{km})\end{array}$ & $\begin{array}{l}\text { Min. } \\
\text { depth } \\
(\mathrm{km})\end{array}$ & $\begin{array}{l}\text { Max. } \\
\text { depth } \\
(\mathrm{km})\end{array}$ & $\begin{array}{c}\text { Average } \\
\text { width } \\
(\mathrm{km})\end{array}$ & Strike & Dip & Rake & $\begin{array}{l}\text { Displacement } \\
(\mathrm{m})\end{array}$ & $\begin{array}{l}\text { Max. } \\
\text { mag. }\end{array}$ & $\begin{array}{l}\text { Ref. } \\
\text { code }\end{array}$ \\
\hline 11 May 1222 & Paphos-Cyprus & 2 & EM & $50 \pm 10$ & $10 \pm 5$ & $20 \pm 5$ & 20 & $125 \pm 10$ & $35 \pm 10$ & $110 \pm 10$ & $3.0 \pm 1.0$ & $7.2 \pm 0.2$ & 18 \\
\hline 8 Aug 1303 & Crete-Dodecanese & 2 & SA & $100 \pm 50$ & $10 \pm 5$ & $20 \pm 5$ & 30 & $115 \pm 5$ & $45 \pm 25$ & $110 \pm 20$ & $8.0 \pm 3.0$ & $8.0 \pm 0.3$ & 17,18 \\
\hline 9 Aug 1912 & Şarköy-Mürefte & 3 & MS & $56 \pm 10$ & $10 \pm 5$ & $25 \pm 5$ & 15 & $68 \pm 5$ & $55 \pm 5$ & $215 \pm 5$ & $4.5 \pm 0.5$ & $7.3 \pm 0.1$ & $3,19,20$ \\
\hline 4 Jan 1935 & Marmara Island & 1 & MS & $20 \pm 5$ & $15 \pm 5$ & $30 \pm 10$ & 20 & $80 \pm 20$ & $50 \pm 10$ & $270 \pm 10$ & & $6.3 \pm 0.1$ & 5,20 \\
\hline 26 Dec 1939 & Erzincan (NAF) & 7 & BS & $350 \pm 10$ & $10 \pm 5$ & $20 \pm 5$ & 10 & $108 \pm 5$ & $86 \pm 5$ & $151 \pm 10$ & $4.0 \pm 1.0$ & $8.0 \pm 0.2$ & $2,8,19,20$ \\
\hline 6 Oct 1944 & Gulf of Edremit-Ayvacik & 1 & $\mathrm{CA}$ & $150 \pm 40$ & $10 \pm 5$ & $30 \pm 10$ & 20 & $56 \pm 10$ & $51 \pm 10$ & $254 \pm 5$ & $0.15 \pm 0.05$ & $6.7 \pm 0.1$ & $6,19,20$ \\
\hline 9 Feb 1948 & Karpathos-Dodecanese & 1 & SA & $180 \pm 30$ & $30 \pm 10$ & $50 \pm 10$ & 25 & $10 \pm 10$ & $28 \pm 15$ & $270 \pm 30$ & & $7.0 \pm 0.2$ & $12,14,18,19,20$ \\
\hline 23 Jul 1949 & Chios-Karaburun & 6 & $\mathrm{CA}$ & $35 \pm 5$ & $5 \pm 2$ & $20 \pm 5$ & 15 & $141 \pm 10$ & $65 \pm 10$ & $322 \pm 10$ & $0.35 \pm 0.1$ & $6.7 \pm 0.1$ & $4,8,19,20$ \\
\hline 10 Sep 1953 & Cyprus & 7 & EM & $25 \pm 5$ & $5 \pm 2$ & $20 \pm 5$ & 20 & $27 \pm 20$ & $73 \pm 5$ & $144 \pm 10$ & $0.35 \pm 0.1$ & $6.2 \pm 0.1$ & $9,13,18,19,20$ \\
\hline 9 Jul 1956 & Amargos-SA & 1 & SA & $100 \pm 5$ & $10 \pm 5$ & $20 \pm 5$ & 10 & $65 \pm 5$ & $40 \pm 15$ & $270 \pm 30$ & 1.0 & $7.5 \pm 0.2$ & $15,16,19$ \\
\hline 23 May 1961 & Rhodes-Marmaris & & SA & & $60 \pm 5$ & $80 \pm 5$ & 20 & $89 \pm 5$ & $62 \pm 5$ & $90 \pm 5$ & & $6.2 \pm 0.1$ & 8,20 \\
\hline 18 Sep 1963 & Çınarcik-Yalova & 1 & MS & $20 \pm 5$ & $25 \pm 10$ & $50 \pm 10$ & 25 & $109 \pm 5$ & $34 \pm 10$ & $259 \pm 10$ & & $6.2 \pm 0.1$ & $2,7,11,20$ \\
\hline 3 Sep 1968 & Bartın-Amasra & 2 & BS & $22 \pm 5$ & $5 \pm 3$ & $10 \pm 3$ & 7 & $43 \pm 10$ & $38 \pm 5$ & $80 \pm 10$ & $0.4 \pm 0.05$ & $6.6 \pm 0.1$ & $1,2,8$ \\
\hline 17 Aug 1999 & Gölcük-Kocaeli & 3 & MS & $120 \pm 10$ & $10 \pm 5$ & $20 \pm 5$ & 15 & $90 \pm 5$ & $85 \pm 5$ & $185 \pm 5$ & $3.0 \pm 0.5$ & $7.5 \pm 0.1$ & $10,19,20$ \\
\hline
\end{tabular}

Fault types:

1 Normal, 2 Thrust, 3 Right-lateral strike-slip, 4 Left-lateral strike-slip, 5 Right-lateral transtensional, 6 Left-lateral transtensional, 7 Right-lateral transpressional, 8 Left-lateral transpressional.

Reference numbers:

1 Alptekin et al. (1985); 2 Altinok and Ersoy (2000); 3 Altinok et al. (2003); 4 Altinok et al. (2005); 5 Altinok and Alpar (2006); 6 Altinok et al. (2007); 7 Armijo et al. (2002); 8 Eyidoğan et al. (1991); 9 Fokaefs and Papadopoulos (2007); 10 Gündoğdu, et al. (2002); 11 Kalafat et al. (2007); 12 Kreemer and Chamot-Rooke (2004); 13 Papadimitriou and Karakostas (2006); 14 Papadopoulos et al. (2007); 15 Papazachos and Anastasia (1996); 16 Perissoratis and Papadopoulos (1999); 17 Tinti et al. (2005); 18 Yolsal et al. (2007); 19 http://www.koeri.boun.edu.tr; 20 http://www.emsc-csem.org/index.php?page=home

Table 2. Some of the most detailed submarine failures (highly probably co-seismic and natural).

\begin{tabular}{llcccccccccc}
\hline Slide name & Basin & Lat $^{\circ} \mathrm{E}$ & Lon $^{\circ} \mathrm{N}$ & $\mathrm{SA}$ & $\mathrm{CV}$ & $\mathrm{EV}$ & HH & WDH & WDB & Age BP & Ref \\
\hline Ganos Complex & W Tekirdă & 27.42 & 40.72 & 78 & NA & 10 & 300 & $100-400$ & 1150 & 12000 & 1 \\
Marmara Island & SW Tekirdağ & 27.6 & 40.75 & 18 & NA & 10 & $300-400$ & 700 & 1150 & 12000 & 1 \\
Tuzla Complex & N Çnarcık & 29.23 & 40.81 & 32.5 & 1.62 & 0.96 & 550 & 200 & 1250 & 17000 & $2,3,4$ \\
\hline
\end{tabular}

SA: total area of disturbed sediment (scar and lobe) in $\mathrm{km}^{2} ; \mathrm{CV}$ : calculated volume in $\mathrm{km}^{3} ; \mathrm{EV}$ : estimated volume in $\mathrm{km}^{3} ; \mathrm{HH}$ : height of headwall in $\mathrm{m}$ (height from failure surface to crown of scar); WDH: waterdepth at top of headwall in m; WDB: waterdepth at base in $\mathrm{m}$ (depth of deepest slide deposit). Ages are stratigraphical extrapolation for Ganos and Marmara Island slides (which are Holocene) and ${ }^{14} \mathrm{C}$ analysis of slide deposits for Tuzla case (Pleistocene). Geotechnical data is available for Tuzla while other cases were estimated from the multibeam bathymetry and reflection data. Reference codes: 1: Altinok et al. (2003); 2: Baş and Alpar (2003); 3: Görür and Çağatay (2010); 4: Özeren et al. (2010).

deposits and foraminiferal assemblage may represent these Late Bronze Age tsunami deposits in Didim, SW Turkey (Minoura et al., 2000). Other sources of tsunamis which have affected the southern coasts of Turkey are mostly regional such as the Rhodes earthquakes (e.g. 1303, 1481, 1609, 1741, 1863). The most distant sources, on the other hand, are the eastern Levantine coast earthquakes (e.g. 140 BC, 859, 1759, 1822, 1872) and Crete earthquakes (e.g. 365).

Most of the historical documents provide sufficient information about the effects of tsunami waves at some locations near the coasts, but these observations are not sufficient to determine the locations and estimate the mechanisms of the sources of these tsunamis. Precise definition of quantitative source parameters is important for representing the generation mechanism of a tsunami and numerical modellings are required to examine their implications. Within the current version of the database, only 14 tsunamigenic event sources could be defined (Table 1). The recurrence interval for tsunami intensities $\geq 3$ is on the order of $30-35$ years.
Submarine landslides, slumps and subsidence events are also responsible for the generation of tsunamis (Yalçıner et al., 2002). As the submarine mass movements on the continental slopes are nearshore, the generated waves arrive at the target shoreline in a short time with low dispersion and they cause extreme run-up (Synolakis et al., 2002). On the basis of recent multi-channel bathymetric data supported by seismic reflection data, numerous paleo-landslides, as well as potential ones, can be observed on the steep continental slopes of the Sea of Marmara, surrounding three deep basins (Fig. 2). The slopes, ranging in depth from $-100 \mathrm{~m}$ to $-1250 \mathrm{~m}$, become steeper offshore Prince Islands and in front of the Tekirdağ shelf $\left(40-50^{\circ}\right)$. At the skirts of the slopes, debris and material masses can be observed, as they have been transported by mass failures. Homogenite deposits in low-lying areas of the Sea of Marmara, which are usually reworked from the basin margins, are related mostly to large earthquakes and probably other seafloor deformations such as tilting, fluid or gas escapes (McHugh et al., 2006). 
The earthquakes on the northern strand of the North Anatolian fault in the Sea of Marmara, which also controls its steep slopes (Yaltırak, 2002), may cause the unstable sediments deposited along the shelf to break and upper slope areas to slide down to the abysal plain during some of the strong earthquakes. Smaller scale underwater sliding structures have also been observed inside the canyon valleys and at their walls. Locations and some characteristics of the most detailed submarine failures were given in Table 2. The Ganos and Tuzla slides seem to be multislumps that have occurred in the same location or as extensions of a previous slide. All of the failure types are debris and generally occur in the proximity of related ruptures. The recurrence interval can be estimated as being more than 1000 years for all cases.

East of the Sea of Marmara, a large ( $7 \mathrm{~km}$ wide) and triangular shaped landslide lies south of Tuzla at depths between -200 and $-1200 \mathrm{~m}$. It has $50 \mathrm{~m}$ thick sediments cutting the slope of the Çınarcık Basin (Görür and Çağatay, 2010). On the basis of ${ }^{14} \mathrm{C}$ analysis, it should have been activated 17000 years ago when the Sea of Marmara was a lake with a water level of -85 to $-95 \mathrm{~m}$ below the present mean sea level (Özeren et al., 2010). In fact, slope failure processes were more common during the last lowstand lacustrine period prior to $12 \mathrm{ka} \mathrm{BP}$ than during the Holocene highstand marine period (Beck et al., 2007). The Tuzla landslide has been defined as a relatively recent and deep-seated rotational landslide (Gökçeoğlu et al., 2009). Considering they have similar depositional characteristics and slope morphology, and also their being prone to a similar tectonic regime, Gökçeoğlu et al. (2009) proposed that the adjoining areas on the eastern and western sides of the Tuzla complex are potential areas for future sliding. Among the landslide scenarios, the most critical and possible ones have surface areas of $20-43 \mathrm{~km}^{2}$ and $14-33 \mathrm{~km}^{2}$ for the western and eastern ones, respectively. The volumes were calculated as $2-4 \mathrm{~km}^{3}$ and $0.5-1.5 \mathrm{~km}^{3}$.

Sarı and Çağatay (2006) defined 3 turbidite levels, which have sharp basal boundaries and contain transported shallow benthic foraminifer species in the cores taken from the northern slopes of the Çınarcık Basin. In such a tectonically active region, historical earthquakes and associated underwater mass flows are the only plausible generation mechanisms for these turbidite levels, since other mechanisms (e.g. river floods, storms, volcanic activities, tides and gas escape) are almost out of the question in this part of the Sea of Marmara region at least since the opening of Bosphorus $(7.2 \mathrm{ka}$ $\mathrm{BP})$. On the basis of their sedimentological characteristics, average linear sedimentation rates and available radiocarbon ages, the turbidite levels were correlated with the following earthquakes; (a) Istanbul-Thrace (intensity $=\mathrm{X}$ ) on 26 October 986; (b) Istanbul-Kocaeli (intensity=IX) on 15 August 553 and (c) some older historical earthquakes during prehistorical times with calculated ages of ca. 3600 and 3800 years BP. The date of the first event may have been written incorrectly by the researchers and it should be identical with the event that occurred on 25 October 989 (Ambraseys, 2002a, b) or 26 October 989 (Guidoboni et al., 1994). Depending on the AMS radiocarbon dating of an enigmatic layer, we recovered $253-311 \mathrm{~cm}$ below from the lake bottom of Küçükçekmece lagoon, which is a coastal wetland protected from the sea by a narrow strip of sandbar (300$350 \mathrm{~m}$ ), we also agree that the 25 October 989 earthquake was tsunamigenic.

In conclusion, the earthquakes in the Sea of Marmara and co-seismic slope failures usually cause damaging tsunamis in certain coastal areas, depending on their source characteristics, distance to the source and bathymetry. Such tsunamis may pose an important threat to the coastal settlements and installations especially located in the gulfs of Izmit and Gemlik, the Kapıdağ Peninsula and on the shores of Istanbul and Gelibolu. Tides are not important in the Sea of Marmara but higher sea-levels due to storm surges may cause tsunamis to become more damaging (Alpar, 2009). Therefore, tsunamis are of practical interest in risk assessment, disaster management and mitigation. Research on the characteristics of near-field tsunamis using tsunami-modeling scenarios will be definitely beneficial. The estimation of source parameters needed in modeling the tsunami waves in the Sea of Marmara and tsunami effects on the coastal areas could be made more reliable with the development of historical information, the determination of potential source areas under the sea and the availability of the underwater topography in a detailed way and using comprehensive modeling.

\section{Conclusion}

Offshore infrastructures, coastal settlements and installations, which are characterised by flat and large beaches, are prone to higher tsunami risk. The tsunami impacts on the coastal waters of Turkey since $1400 \mathrm{BC}$ were re-examined following the catalogue guidelines defined in EU projects of GITEC and TRANSFER.

Most of the tsunami events in the database are associated with different fault segments. The East Aegean Arc and trench system in the Southern Aegean Sea and the North Anatolian fault system in the Sea of Marmara constitute the highest tsunamigenic potentials in the region, both for the number of occurrences and their intensity. Although the repeatability of Black Sea tsunamis is low, some destructive tsunamis with large run-ups and inundation distances have been reported. Most of the strong earthquakes $(M>6.5)$ offshore the Black Sea can be assumed as being potential tsunamigenic sources. Many coastal settlements in the Eastern Mediterranean have been struck in the past by large and destructive tsunamis generated by submarine earthquakes and volcanic eruptions. Considering the high seismicity of the Aegean-Cyprean Arc, earthquake-related slope failures are also a plausible triggering mechanism for powerful tsunamis. The recurrence interval is $35-65$ years 
for moderate events $(\mathrm{TI}<4)$, while for strong tsunami events $(\mathrm{TI} \geq 4)$ it is on the order of $90-110$ years. Some of the tsunamis in the Sea of Marmara might have been triggered by underwater sedimentary disturbances occurring during major earthquakes. Most of the largest slope failures and sediments flows, however, occurred at the end of the last glacial period (12-17 ka BP) when this inland sea was lacustrine ( -85 to $-95 \mathrm{~m}$ ) before the transition to marine conditions. Therefore, the database of tsunamis prepared in the present study with their geological traces, provides reference material for validating digital simulations of historical events and represents a valuable basis for hazard/risk assessment.

Acknowledgements. The present work was made wihin the framework of work-packages WP1-3 of TRANSFER. We would like to thank Stefano Tinti, project coordinator, Alessandra Maramai, Gerassimos Papadopoulos, David Long and Daniella Pantosti, the work package leaders. Research funds were allocated from the Istanbul University projects UDP-503/15022007 and the project TRANSFER (Tsunami Risk and Strategies For the European Region) supported by the EU contract n. 037058, FP6-2005-Global-4.

Edited by: S. Tinti

Reviewed by: two anonymous referees

\section{References}

Alpar, B.: Vulnerability of Turkish coasts to accelerated sea-level rise, Geomorphology, 107, 58-63, 2009.

Alptekin, Ö., Nabalek, J. L., and Toksöz, N.: 3 Eylül 1968 Bartın Depreminin kaynak mekanizması ve Karadeniz'in aktif tektonigi hakkında düsünceler, Deprem Arastırma Bülteni, 50, 5-28, 1985 (in Turkish).

Altınok, Y. and Alpar, B.: Marmara Island earthquakes, of 1265 and 1935; Turkey, Nat. Hazards Earth Syst. Sci., 6, 999-1006, doi:10.5194/nhess-6-999-2006, 2006.

Altinok, Y. and Alpar, B.: Marmara tsunamileri, olası deniz içi kaynakları ve yerlesim alanlarına etkileri, İstanbul'un Jeolojisi Sempozyumu III, 07-09 Aralık 2007, Bildiriler Kitabı, İstanbul, 343359, 2010 (in Turkish).

Altinok, Y. and Ersoy, Ş.: Tsunamis observed on and near the Turkish Coast, Nat. Hazards, 21, 185-205, 2000.

Altinok, Y., Tinti, S., Alpar, B., Yalçıner, A. C., Ersoy, Ş., Bortolucci, E., and Armigliato, A.: The tsunami of August 17, 1999 in Izmit Bay, Turkey, Nat. Hazards, 24, 133-146, 2001.

Altinok, Y., Alpar, B., and Yaltırak, C.: Sarkoy-Murefte 1912 Earthquake's tsunami, extention of the associated faulting in the Marmara Sea, Turkey, J. Seismol., 7, 329-346, 2003.

Altinok, Y., Alpar, B., Özer, N., and Gazioglu, C.: 1881 and 1949 earthquakes at the Chios-Cesme Strait (Aegean Sea) and their relation to tsunamis, Nat. Hazards Earth Syst. Sci., 5, 717-725, doi:10.5194/nhess-5-717-2005, 2005.

Altinok, Y., Alpar, B., and Özer, N.: 6 October 1944 Ayvacik earthquake and associated tsunami; Gulf of Edremit, Turkey, EGU General Assembly, Vienna, Austria, 15-20 April 2007, Geophys. Res. Abstr., 9, 01979, 2007.

Altinok, Y., Alpar, B., Özer, N., Ünlü, S., Meriç, E., Nazik, A., Avşar, N., Balkıs, N., Aykurt, H., and Taş, S.: Black Sea tsunamis and paleotsunami studies on the Thrace Coasts of Turkey, Proceedings of MEDCOAST09 International Conference, 10-14 November 2009, Sochi, Russia , 931-942, 2009.

Ambraseys, N. N.: The seismic sea wave on July 9, in the Greek Archipelago, J. Geophys. Res., 65(4), 1257-1265, 1960.

Ambraseys, N. N.: Data for the investigation of the seismic seawaves in the Eastern Mediterranean, Bull. Seism. Soc. Am., 52, 895-913, 1962.

Ambraseys, N. N.: Engineering Seismology, J. Earthq. Eng. Struct. Dyn., 17/1-105, 1988.

Ambraseys, N. N.: Seismic sea waves in the Marmara Sea region during the last 20 centuries, J. Seismol., 6, 571-578, 2002a.

Ambraseys, N. N.: The Seismic Activity of the Marmara Sea Region over the Last 2000 Years, Bull. Seism. Soc. Am., 92, 1-18, 2002 b.

Ambraseys, N. N. and Finkel, C. F.: The Saros-Marmara earthquake of 9 August 1912, Earthquake Eng. Struct. Dyn., 15, 189-211, 1987.

Ambraseys, N. N. and Finkel, C.: The seismicity of Turkey and adjacent areas; A historical review: 1500-1800, Eren Yayıncılık, Istanbul, 1995.

Antonopoulos, A.: Contribution to the knowledge of tsunamis in the Eastern Mediterranean from ancient times until the recent, Ann. Geol. Des. Pays. Helleniques, T XXIX(2), 740-757, 1987.

Antonopoulos, J.: Catalogue of tsunamis in the Eastern Mediterranean from antiquity to present times, Ann. Geofis., 32, 113130, 1979.

Armijo, R., Meyer, B., Navarro, S., King, G., and Barka, A.: Asymmetric slip partitioning in the Sea of Marmara pull-apart: a clue to propagation processes of the North Anatolian Fault?, Terra Nova, 14, 80-86, 2002.

Baş, M. and Alpar, B.: Structural features of the Tuzla Region, İstanbul, Turkish J. Marine Sciences, 9(2), 79-110, 2003.

Beck, C., Mercier de Lapinay, B., Schneider, J. L., Cremer, M., Çağatay, N., Wendenbaum, E., Boutareaoud, S., Menot, G., Schmidt, S., Webe, O., Eriş, K., Armijo, R., Meyer, B., Pondard, N., Gutcher, M. A., Turon, J. L., Labeyrie, L., Cortijo, E., Gallet, Y., Bouquerel, H., Görür, N., Geravis, A., Castera, M. H., Londeix, L., de Resseguier, A., and Jaouen, A.: Late Quaternary co-seismic sedimentation in the Sea of Marmara's deep basins, Sediment Geol., 199, 65-89, 2007.

Birand, S. A.: Depremler, Sebepleri, Korunma Yolları, Yüksek Ziraat Enstitüsü Basımevi, Ankara, 1944 (in Turkish).

BOA: Turkish Republic Prime Ministry, General Directorate of the State (Ottoman) Archives: YEE, 91/ 19, 1321 in Ottoman Mali/Rumi Era (in Ottoman).

Bozkurt, E.: Neotectonics of Turkey - a synthesis, Geodinamica Acta, 14(1-3), 3-30, 2001.

Bryant, E.: Tsunami, Cambridge University Press, United Kingdom, 320 pp., 2001.

Calvi, V. S.: Erdbebenkatalog der Türkei und Einiger Benaehbarter Gebiete (unpublished), Report No. 276, MTA Enstitüsü, Ankara, 1941.

Dotsenko, S. F. and Eremeev, V. N.: Analysis of the necessity and Possibility of tsunami early warning on the Black-Sea Coast, Physical Oceanography, 18(5), 288-296, 2008.

Eginitis, D.: 1310 Zelzelesi hakkında rapor, Başbakanlık Osmanlı Arşivi, YEE 11/24, 1894 (in Ottoman). 
EMSC (European Mediterranean Seismological Centre): http:// www.emsc-csem.org/, last access date 18 February 2010.

Eyidoğan, H., Güçlü, U., Utku, Z., and Değirmenci, E.: Türkiye Büyük Depremleri Makro-sismik Rehberi (1900-1988), ITU Maden Fakültesi, İstanbul, 1991 (in Turkish).

Fokaefs, A. and Papadopoulos, G.: Tsunami hazard in the Eastern Mediterranean: strong earthquakes and tsunamis in Cyprus and the Levantine Sea, Nat. Hazards, 43(3), 503-526, 2007.

Galanopoulos, A. G.: Tsunamis observed on the coasts of Greece from antiquity to present time, Ann. Geofis., 13, 369-386, 1960.

GITEC Catalogue (Genesis and Impact Tsunami on European Coast-Tsunami Warning and Observations), financed by the European Union under the contract ENV4-CT96-0297.

Gökçeoğlu, C., Tunusluoğlu, M. C., Görüm, T., Tur, H., Gökaan, E., Tekkeli, A. B., Batuk, F., and Alp, H.: Description of dynamics of the Tuzla Landslide and its implications for further landslides in the northern slope and shelf of the Cinarcik Basin (Marmara Sea, Turkey), Eng. Geol., 106, 133-153, 2009.

Görür, N. and Çağatay, M. N.: Geohazards rooted from the northern margin of the Sea of Marmara since the late Pleistocene: a review of recent results, Nat. Hazards, 54(2), 583-603, 2010.

Guidoboni, E. and Comastri, A.: Catalogue of earthquakes and tsunamis in the Mediterrenean Area from the 11th to the 15th century, ISBN: 88-85213-10-3, Instituto Nazionale di Geofisica e Vulcanologia, Italy, 2005.

Guidoboni, E., Comastri, A., and Traina, G.: Catalogue of Ancient Earthquakes in the Mediterranean Area up to the 10th Century, Instituto Nazionale di Geofisica, Rome, 1994.

Gündoğdu, O., Altinok, Y., Akkargan, 1. Sayın, N., Hisarli, M., Özçep, F., Özçep, T., and Özer, N.: 17 Ağustos 1999 Gölcük Depremi Araştırması, Report, Istanbul University, Research Fund, Project no: 1383/081299, Istanbul, 2002 (in Turkish).

Heck, N. H.: List of seismic sea waves, Bull. Seism. Soc. Am., 37, 269-286, 1947.

İkdam: 25 April 1901, 1901 (newspaper in Ottoman).

Kalafat, D., Güneş, Y., Kara, M., Deniz, P., Kekovali, K., Küleli, H. S., Gülen, L., Yılmazer, M., and Özel, N. M.: A Revised and Extended Earthquake Cataloque for Turkey since 1900 (M>=4.0), KOERI, Bogazici University, Istanbul, 2007.

Karnik, V.: Seismicity of the European Area, vol. 2, Reidel, Dordrecht, Holland, 1971.

KOERI (Kandilli Observatory): www.koeri.boun.edu.tr, last access date 8 December 2010.

Kreemer, C. and Chamot-Rooke, N.: Contemporary Kinematics of the Southern Aegean and Mediterrenean Ridge, Geophys. J. Int., 157, 1377-1392, 2004.

Kuran, U. and Yalçıner, A. C.: Crack propogations earthquakes and tsunamis in the vicinity of Anatolia, in: Fifteenth International Tsunami Symposium, 1991, Tsunamis in the World, edited by: Tinti, S., Kluwer Academic Publishers, Holland, pp. 159-175, 1993.

Le Pichon, X., Şengör, A. M. C., Demirbağ, E., Rangin, C., İmren, C., Armijo, R., Görür, N., Çağatay, N., Mercier de Lepinay, B., Meyer, B., Saatçılar, R., and Tok, B.: The main Marmara fault, Earth Planet. Sci. Lett., 192, 595-616, 2001.

Luttrell, A.: Earthquakes in Dodecanese; 1303-1513, in: Natural Disasters in the Ottoman Empire, edited by: Zachariadou, E., Crete University Press, 145-151, 1999.

McHugh, C. M. G., Seeber, L., Cormier, M. H., Dutton, J., Çă̆atay,
N., Polonia, A., Ryan, W. B. F., and Görür, N.: Submarine earthquake geology along the North Anatolia Fault in the Marmara Sea, Turkey: A model for transform basin sedimentation, Earth Planet. Sci. Lett., 248, 661-684, 2006.

Minoura, K., Imamura, F., Kuran, U., Nakamura, T., Papadopoulos, G. A., Takahashi, T., and Yalçıner, A. C.: Discovery of Minoan tsunami deposits, Geology, 28, 59-62, 2000.

Moreria, V. S.: Earthquakes and tsunamis in the European area, H. Soysal's archive, Istanbul, 1971.

Murty, T. S.: Seismic Sea Waves, Tsunamis, Department of Fisheries and Environment Fisheries and Marine Service, Scientific Information and Publication Branch, Ottawa, Canada, 337 pp., 1977.

Nikonov, A.: Tsunami occurrence on the coast of the Black Sea and the Sea of Azov, Izvestiya, Phys. Solid Earth, 33(1), 77-87, 1997a.

Nikonov, A.: Tsunami - a threat from the south? Search and Development, Science in Russia, 6, 13-19, 1997b.

Ozansoy, E.: Antakya earthquakes from Ioannis Malalas' chronography, Mesogeios Mediterrenee, 3, 83-98, Heredetos/Kadmos, Paris, 1999 (in Greek).

Ozansoy, E.: Bizans kaynaklarına göre 1200-1453 Istanbul depremleri, in: Tarih Boyunca Anadolu'da Doğal Afetler ve Deprem Semineri Bildiriler Kitabı (22-23 May1s 2000), 1-29, Istanbul Üniversitesi, Edebiyat Fakültesi Tarih Araştırma Merkezi, Istanbul, 2001 (in Turkish).

Özçiçek, B.: 18 Eylül 1963 Doğu Marmara depremi etüdü, Jeofizik, 1(2), 49-69, 1966-1967 (in Turkish).

Özeren, M. S., Çağatay, M. N., Postacioğlu, N., Şengör, A. M. C., Görür, N., Eriş, K.: Mathematical modelling of a potential tsunami associated with a late glacial submarine landslide in the Sea of Marmara, Geo-Mar Lett., 30, 523-539, 2010.

Öztin, F.: 10 Temmuz 1894 Istanbul Depremi Raporu, T.C. Bayındırlık ve Iskan Bakanlığı, Afet Işleri Genel Müdürlüğü, Deprem Araştırma Dairesi, Ankara, 1994 (in Turkish).

Öztin, F. and Bayülke, N.: Historical earthquakes of Istanbul, Kayseri, Elazıg, in: Proc. Workshop on Historical Seismicity and Seismotectonics of the Mediterranean Region, 10-12 October 1990 (Istanbul), Turkish Atomic Energy Authority, Ankara, 150 173, 1991.

Papadimitriou, E. E. and Karakostas, V. G.: Earthquake generation in Cyprus revealed by the evolving stress field, Tectonophysics, 423, 61-72, 2006.

Papadopoulos, G. A.: Seismic faulting and nonseismic tsunami generation in Greece, in: Proc. IUGG/IOC International Tsunami Symposium, 23-27 August, Wakayama, Japan, pp. 115-123, 1993.

Papadopoulos, G. A. and Chalkis, B. J.: Tsunamis observed in Greece and the surrounding area from antiquity to the present times, Mar. Geol., 56, 309-317, 1984.

Papadopoulos, G. A. and Imamura, F.: A proposal for a new tsunami intensity scale, International Tsunami Symposium 2001, Proceedings, National Oceanic and Atmospheric Administration, Seattle, Washington, US, Session 5, Number 5-1, 569-577, 2001.

Papadopoulos, G. A., Daskalaki, E., Fokaefs, A., and Giraleas, N.: Tsunami hazards in the Eastern Mediterranean: strong earthquakes and tsunamis in the East Hellenic Arc and Trench system, Nat. Hazards Earth Syst. Sci., 7, 57-64, doi:10.5194/nhess-7-57- 
2007, 2007.

Papazachos, C. B. and Anastasia, A. K.: A detailed study of the active crustal deformation in the Aegean and surrounding area, Tectonophysics, 253, 129-153, 1996.

Papazachos, B. C. and Papazachou, C. B.: The earthquakes of Greece, Editions Ziti Publication Co., Thessaloniki-Greece, 356 pp., 1997.

Papazachos, B. C., Koutitas, Ch., Hatzidimitriou, P. M., Karacostas, B. G., and Papaioannou, Ch. A.: Tsunami hazard in Greece and the surrounding area, Ann. Geophys., 4B(1), 79-90, 1986.

Parejas, I., Akyol, M., and Altınlı, E.: Le tremblement de terre d'Erzincan du 27 Decembre 1939 (secteur occidental), I.Ü. Jeoloji Enstitüsü Neşriyatı, 10, 187-222, 1942.

Perissoratis, C. and Papadopoulos, G.: Sediment instability and slumping in the southern Aegean Sea and the case history of the 1956 tsunami, Mar. Geol., 161, 287-305, 1999.

Poirier, J. P. and Taher, M. A.: Historical seismicity in the near and middle east, North Africa, and Spain from Arabic documents (VII-XVIIIth century), Bull. Seism. Soc. Am., 70, 2185-2201, 1980.

Rangin, C., Demirbağ, E., Imren, C., Crusson, A., Normand, A., Le Drezen, E., and Le Bot, A.: Marine Atlas of the Sea of Marmara (Turkey), IFREMER-Brest Technology Center, Paris, France, 2001.

Ranguelov, B.: Earthquakes and tsunami hazards in the Black Sea, In: Abstract Book of the First Congress of the Balkan Geophysical Society, 23-27 September, Athens, pp. 44-45, 1996a.

Ranguelov, B.: Seismicity and Tsunamis in the Black Sea, in: Seismology in Europe, XXV Gen. Ass. ESC, Reykjavik, 9-14 September 1996, pp. 667-673, 1996b.

Ranguelov, B.: Tsunami repeatability for the Black Sea, Proceedings of the 1-st International Conference, Port Coast Environment, Varna, Bulgaria, pp. 293-297, 30 June-4 July 1997.

Ranguelov, B.: Possible tsunami deposits discovered on the Bulgarian Black Sea coast and some implications., in: Submarine Landslides and Tsunamis, editing by: Yalçıner, A., Pelinovsky, E., Okal, E., and Synolakis, C., Kluwer Acad. Publ., pp. 237242, 2003.

Ranguelov, B. and Gospodinov, D.: Tsunami vulnerability modelling for the Bulgarian Black Sea Coast., Wat. Sci. Tech., 32(7), 47-53, 1995.

Ranguelov, B., Tinti, S., Pagnoni, G., Tonini, R., Zaniboni, F., and Armigliato, A.: The nonseismic tsunami observed in the Bulgarian Black Sea on May, 7th 2007. Was it due to a submarine landslide?, Geophys. Res. Lett., 35, L18613, doi:10.1029/2008GL034905, 2008.

Reinhardt, E. G., Goodman, B. N., Boyce, J. I., Lopez, G., van Henstum, P., Rink, W. J., Mart, Y., and Raban, A.: The tsunami of 13 December A.D. 115 and the destruction of Herod the Great's harbor at Caesarea Maritima, Israel, Geology, 34(12), 1061-1064, 2006.

Rothaus, R. M., Reinhardt, E., and Noller, J.: Regional considerations of coastline change, tsunami damage and recovery along the Southern coast of the Bay of Izmit (The Kocaeli- Turkey Earthquake of 17 August 1999), Nat. Hazards, 31, 233-252, 2004.

Sakin, O.: Tarihsel Kaynaklara Göre Istanbul Depremleri, Kitabevi, Istanbul, 2002 (in Turkish).

Sarı, E. and Çağatay, M. N.: Turbidites and their association with past earthquakes in the deep Çınarcık Basin of the Marmara Sea, Geo-Mar. Lett., 26, 69-76, 2006.

Şaroğlu, F., Emre, Ö., and Kusçu, İ.: 1/1,000,000 Ölçekli Türkiye Diri Fay Haritas1, Directorate of Mineral Research and Exploration (MTA), Ankara, 1992.

Sbeinati, M. R., Darawcheh, R., and Mouty, M.: The historical earthquakes of Syria: an analysis of large and moderate earthquakes from 1365 B.C. to 1900 A.D., Ann. Geophy.-Italy, 48(3), 347-435, 2005.

Shebalin, N. V., Karnik, V., and Hadzievski, D.: Catalogue of Earthquakes, UNESCO, Skopje, Yugoslavia, 1974.

Soloviev, S. L., Solovieva, O. N., Go, C. N., Kim, K. S., and Shchetnikov, N. A.: Tsunamis in the Mediterranean Sea 2000 B.C.2000 A.D., Kluwer Academic Publishers, Netherlands, pp. 237, 2000.

Soysal, H.: Tsunami (deniz taşması) ve Türkiye kıyılarını etkileyen tsunamiler, Istanbul Üniversitesi, Deniz Bilimleri ve Coğrafya Enstitüsü Bülteni, 2, 59-67, 1985 (in Turkish).

Soysal, H., Sipahioğlu, S., Kolçak, D., and Altinok, Y.: Türkiye ve Çevresinin Tarihsel Deprem Kataloğu (MÖ 2100-MS 1900), TÜBITAK, TBAG Proje No. 341, Istanbul, 1981 (in Turkish).

Stiros, S. C.: The 8.5+ magnitude, AD365 earthquake in Crete: coastal uplift, topography changes, archaeological and historical signature, Quatern. Int., 216, 54-63, 2010.

Synolakis, C. E., Bardet, J. P., Borrero, J., Davies, H. L., Okal, E. A., Silver, E. A., Sweet, S., and Tappin, D. R.: The slump origin of the 1998 Papua New Guinea tsunami, Proc. Royal Society Lond., Series A, 458, 763-789, 2002.

Tinti, S., Maramai, A., and Graziani, L.: A new version of the European tsunami catalogue: updating and revision, Nat. Hazards Earth Syst. Sci., 1, 255-262, doi:10.5194/nhess-1-255-2001, 2001.

Tinti, S., Armigliato, A., Pagnoni, G., and Zaniboni, F.: Scenarios of giant tsunamis of tectonic origin in the Mediterrenean, ISET Journal of Earthquake Technology, 42(4), 171-188, 2005.

Tinti, S., Armigliato, A., Manucci, A., Pagnoni, G., Zaniboni, F., Yalçıner, A. C., and Altinok, Y.: The generating mechanisms of the August 17, 1999 Izmit bay (Turkey) tsunami: regional (tectonic) and local (mass instabilities) causes, Mar. Geol., 225, 311-330, 2006.

Ulus: 24 May 1961 (newspaper, in Turkish).

UNESCO/IOC (Global Tsunami Website): http: //www.ioc-tsunami.org/index.php?option=com content \&view $=$ article $\&$ id $=16$ : tsunamicatalogue $\&$ catid $=12$ : ne-atlantic-a-med\&Itemid $=16 \&$ lang $=$ en, last access date 6 January 2011.

Vatin, N.: Les tremblements de terre à Rhodes en 1481 et leur historien, Guillaume Caoursin, in: Natural Disasters in the Ottoman Empire, edited by: Zachariadou, E., Crete University Press, 153184, 1999.

Vilibić, I., Šepić, J., Ranguelov, B., Mahović, N. S., and Tinti, S.: Possible atmospheric origin of the 7 May 2007 western Black Sea shelf tsunami event, J. Geophys. Res., 115, C07006, doi:10.1029/2009JC005904, 2010.

Vogt, J.: Sismicité historique du domaine Otoman: types de sources occidentales et exemples de temoignages, in: Natural Disasters in the Ottoman Empire, edited by: Zachariadou, E., Crete University Press, 15-53, 1999.

Wedding, H.: 3 EyIül 1968 de vukua gelen Bartın-Amasra yer- 
sarsintıs1, MTA Dergisi, 71, 135-141, 1968 (in Turkish).

Wessel, P. and Smith, W. H. F.: New, improved version of Generic Mapping Tools released, EOS, 79, 579, 1998.

Yalçıner, A. C., Synolakis, C. E., Borrero, J., Altinok, Y., Watts, P., Imamura, F., Kuran, U., Ersoy, Ş., Kanoğlu, U., and Tinti, S.: Tsunami generation in Izmit Bay by the Izmit Earthquake, Proceedings ITU-IAHS International Conference on the Kocaeli Earthquake 17 August 1999, Istanbul, 217-220, 1999.

Yalçıner, A. C., Altinok, Y., and Synolakis, C.: Tsunami waves in Izmit Bay, Earthquake Spectra, The Professional Journal of the Earthquake Research Institute, 16, 55-62, 2000.

Yalçıner, A. C., Alpar, B., Altinok, Y., Özbay, I., and Imamura, F.: Tsunamis in the Sea of Marmara: Historical documents for the past, models for the future, Mar. Geol., 190, 445-463, 2002.
Yalçıner, A. C., Pelinovski, E., Talipova, T., Kurkin, A., Kozelkov, A., and Zaitsev, A.: Tsunamis in the Black Sea: comparison of the historical, instrumental, and numerical data, J. Geophys. Res.-Oceans, 109(C12), C12023, doi:10.1029/2003JC002113, 2004.

Yaltırak, C.: Tectonic evolution of the Marmara Sea and its surroundings, Mar. Geol., 190, 493-529, 2002.

Yeni Sabah: 10 July 1956 (newspaper, in Turkish).

Yolsal, S., Taymaz, T., and Yalçıner, A. C.: Understanding tsunamis, potential source regions and tsunami prone mechanisms in the Easrtern Mediterrenean, The Geodynamics of the Aegean and Anatolia, The Geological Society, Special Publication, pp 201-230, London, 2007. 